\title{
Rozdział 6
}

\section{Współczesna ewolucja rzeźby Kotlin Podkarpackich}

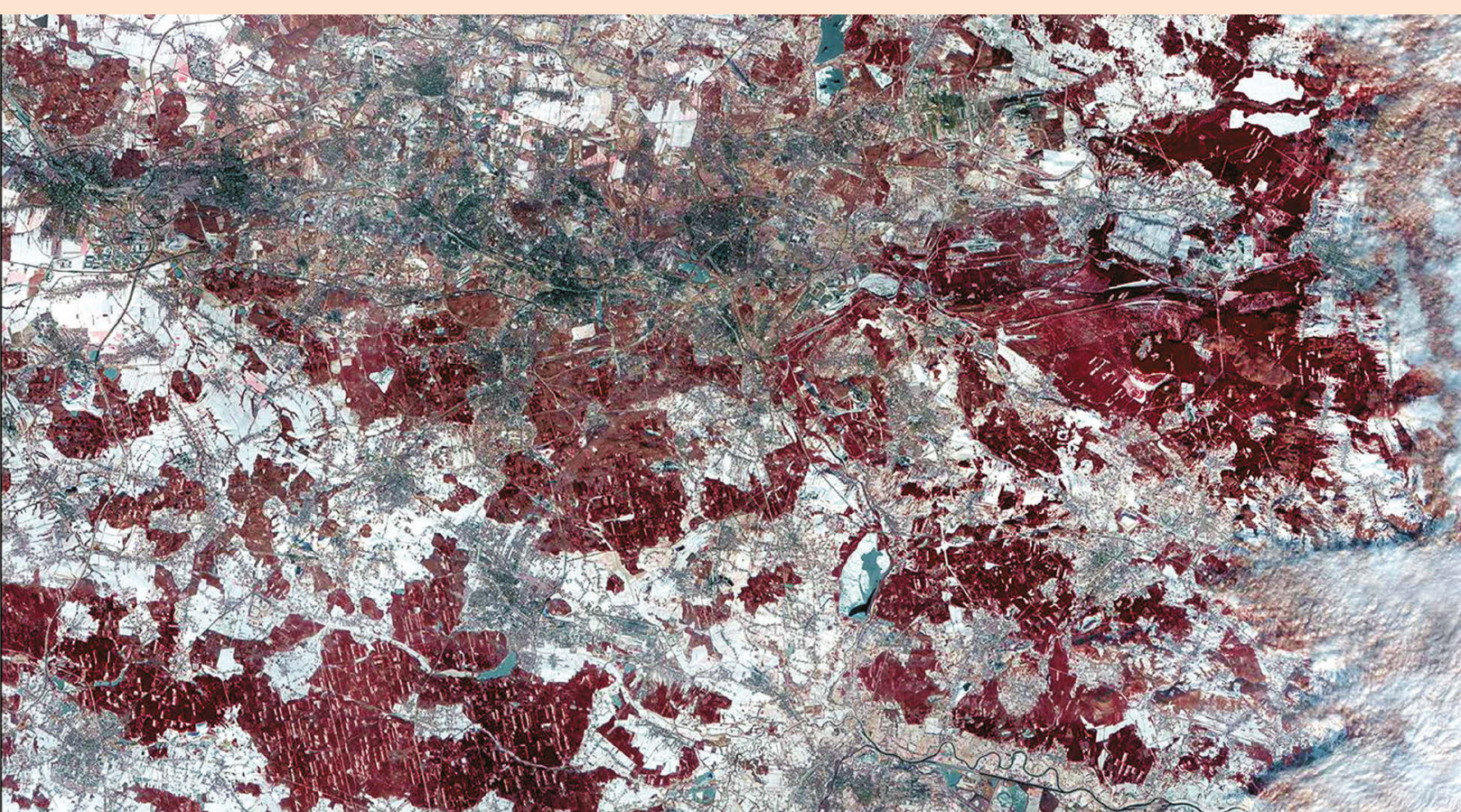

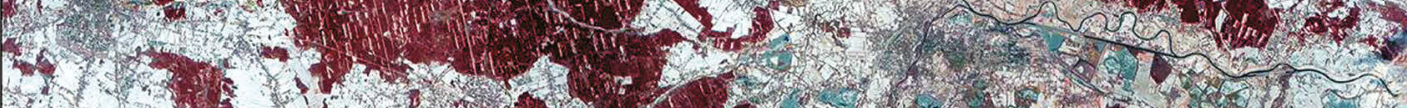

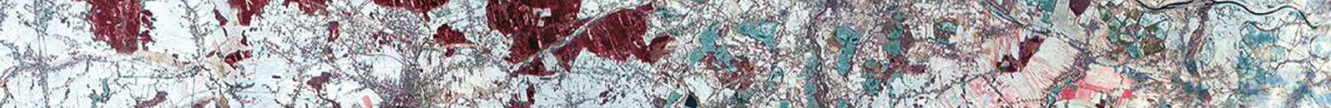

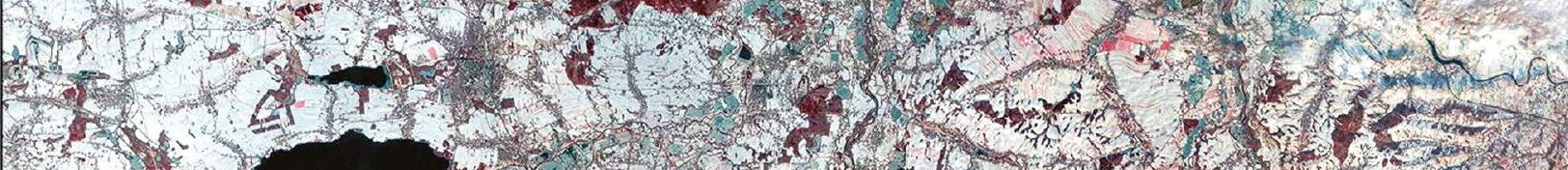

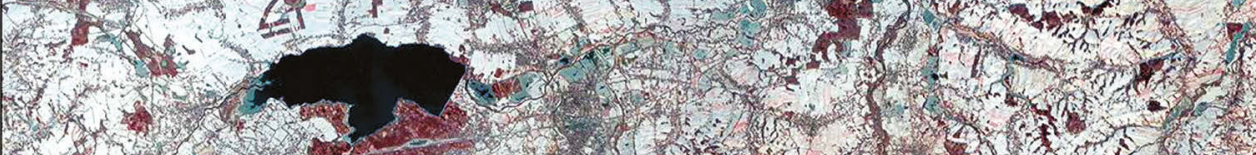
Hof

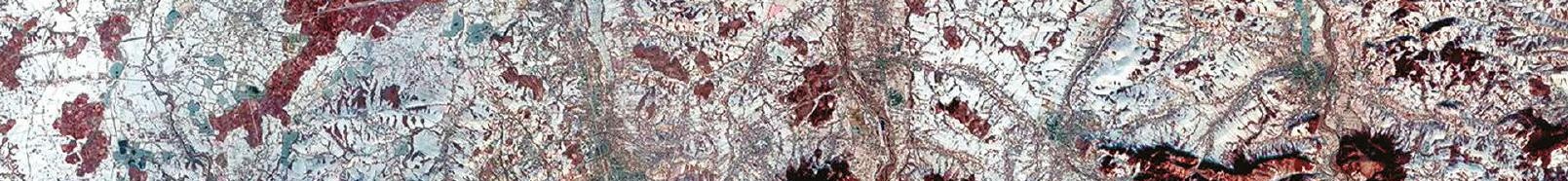

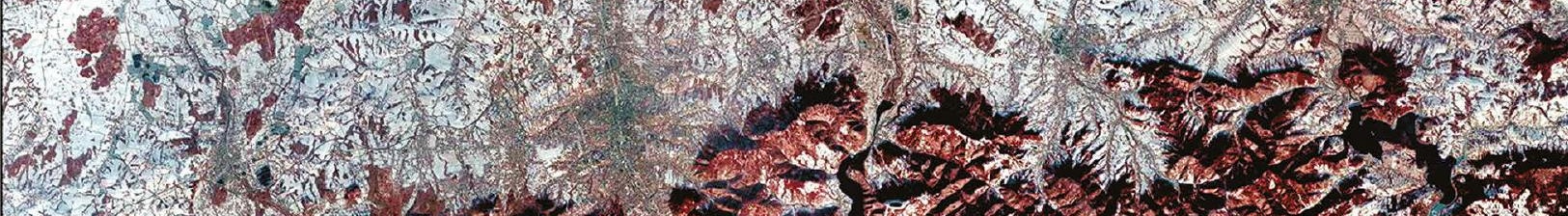
$-7 T_{0}$ 
Kotlina Oświęcimska (ESA/Copernicus) 
W: Wspótczesne przemiany rzeźby Polski, A. Kostrzewski, K. Krzemień, P. Migoń, L. Starkel, M. Winowski, Z. Zwoliński (red.), Bogucki Wydawnictwo Naukowe, Poznań, 2021 https://doi.org/10.12657/9788379863822-06

\section{(c) $\underset{\text { (i) }}{\text { 8צ40 }}$ \\ Rozdział 6 \\ Współczesna ewolucja rzeźby Kotlin Podkarpackich \\ Piotr Gębica, Leszek Starkel, Agnieszka Czajka, Renata Dulias, Maria Fajer, Jan Maciej Waga}

Kotliny Podkarpackie ciągną się na przedpolu Karpat Zewnętrznych fliszowych i Sudetów Wschodnich, przechodząc na wschód od granic Polski w Wysoczyzny Wschodniego Przedkarpacia leżące w dorzeczu górnego Dniestru na Ukrainie, a na zachodzie przez Bramę Morawską łączą się z kotlinami północnego przedpola Alp w dorzeczu Dunaju. Od północy granicę Kotlin Podkarpackich wyznaczają wzniesienia Wyżyny Śląsko-Małopolskiej, Wyżyny Lubelskiej i Roztocza, wchodzące w skład wału metakarpackiego. Południową granicę kotlin stanowi próg Pogórza Karpackiego, natomiast południowo-zachodnią wyznacza krawędź Sudetów Wschodnich. Przewężenie Bramy Krakowskiej między Wyżyną Krakowsko-Częstochowską a Pogórzem Wielickim dzieli je na dwie części. Część wschodnia, znacznie rozleglejsza, nosi nazwę Kotliny Sandomierskiej, część zachodnią określa się jako Kotlinę Raciborsko-Oświęcimską (Klimek, Starkel 1972, Starkel 1972, Gilewska 1999). Kotlina Oświęcimska leży w dorzeczu górnej Wisły, natomiast Kotlina Raciborska w dorzeczu górnej Odry i przechodzi ku zachodowi w rozległą Nizinę Śląską. Granica między tymi dwoma makroregionami przebiega na linii Krapkowice-Głuchołazy (Brama Krapkowicka) (Klimek, Starkel 1972).

\subsection{Kotlina Raciborsko-0święcimska}

\subsubsection{Położenie i podział}

Kotlina Raciborsko-Oświęcimska leży w zachodniej części Kotlin Podkarpackich. Według M. Klimaszewskiego (1972) oraz K. Klimka i L. Starkla (1972) oprócz Kotliny Raciborskiej należy do niej również Płaskowyż Głubczycki. S. Gilewska (1999), podobnie jak S. Szczepankiewicz (1972), zaliczyli obie te jednostki do Niziny Śląskiej, zaś P. Migoń (2008) traktuje Płaskowyż Głubczycki jako wyżynne 


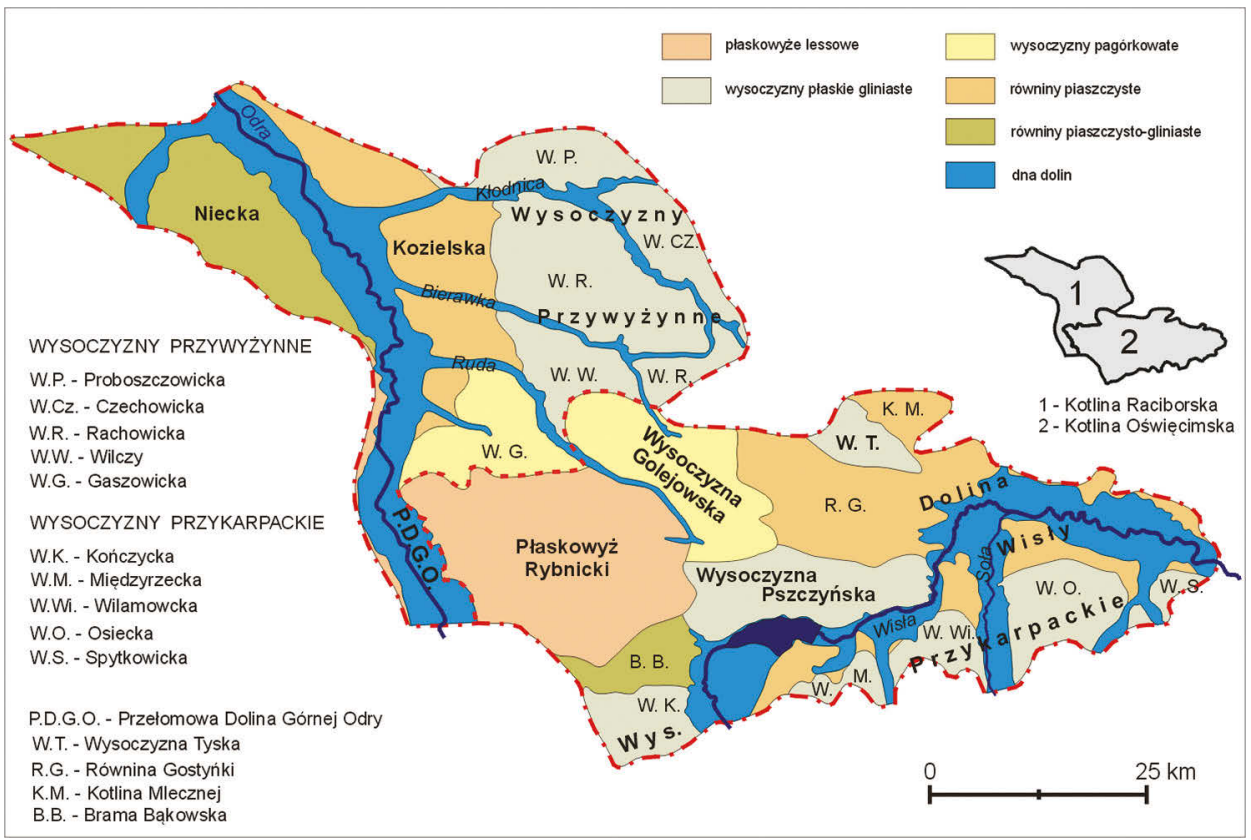

Ryc. 6.1. Kotlina Raciborsko-Oświęcimska - jednostki geomorfologiczne i typy rzeźby, mapa opracowana na podstawie prac K. Klimka, L. Starkla (1972) i S. Gilewskiej (1999), zmieniona i uzupełniona

przedpole Sudetów Wschodnich. Autorzy, uwzględniając przejściowo-łącznikowy charakter Kotliny Raciborskiej (szczególnie jej północnej części - Niecki Kozielskiej), między Kotlinami Podkarpackimi a Niziną Śląską, opisali ją razem z Kotliną Oświęcimską (ryc. 6.1). Najwyższą częścią kotliny, wzniesioną do $310 \mathrm{~m}$ n.p.m., jest Płaskowyż Rybnicki, dlatego w regionalizacji fizycznogeograficznej zaliczono go do Wyżyny Śląskiej (Kondracki 1981). Zamyka on Kotlinę Oświęcimską od zachodu.

\subsubsection{Charakterystyka środowiska przyrodniczego}

Obszar Kotliny Raciborsko-Oświęcimskiej leży w obrębie zachodniej części zapadliska przedkarpackiego. Dno tego zapadliska wypełniają osady miocenu, głównie morskiego - iły i iłowce, lokalnie z gipsami, siarką i solą. Miąższość osadów mioceńskich jest bardzo zróżnicowana, od kilkuset metrów w rowach tektonicznych do kilku metrów nad zrębami (Klimek, Starkel 1972, Lewandowski 2015). Powierzchnia osadów mioceńskich jest porozcinana kopalnymi dolinami. Ich sieć należy do systemów pra-Wisły i pra-Odry, m.in. dolina biegnąca równoleżnikowo osią zapadliska na linii Oświęcim-Racibórz czy najgłębsza z tych form - dolina/ rynna Rudy (Lewandowski 1993). Obszar kotliny pokrywają utwory czwartorzędowe o zróżnicowanej genezie (glacjalne, fluwioglacjalne, eoliczne, fluwialne, 
antropogeniczne) i zmiennej miąższości. Lokalnie, m.in. w Paprocanach i Bieruniu, ponad powierzchnię zasypania czwartorzędowego wznoszą się pagóry zrębowe zbudowane ze skał karbońskich i triasowych (Klimek, Starkel 1972).

Rzeźba Kotliny Raciborsko-Oświęcimskiej ma na wielu obszarach cechy przejściowe pomiędzy rzeźbą wyżynną i nizinną. Występują tam cztery główne typy ukształtowania terenu (ryc. 6.1): 1 - płaskowyże oraz wysoczyzny, o cokołach utworzonych z utworów wieku mioceńskiego (lokalnie starszego) nadbudowane glinami morenowymi, ich reziduum, utworami wodnolodowcowymi, a także lessami, 2 - faliste równiny denudacyjne wykształcone na osadach lodowcowych i wodnolodowcowych, lokalnie przemodelowane przez procesy eoliczne, 3 - równiny piaszczystych teras nadzalewowych i stożków napływowych, lokalnie przemodelowane przez procesy eoliczne oraz 4 - równiny teras zalewowych.

Współczesna rzeźba kotliny jest wynikiem działalności wielu czynników morfotwórczych, zmieniających swoją aktywność wraz z powtarzającymi się wahaniami klimatu. Pierwszym z tych czynników był wpływ lądolodów skandynawskich na akumulację utworów lodowcowych i wodnolodowcowych w kotlinach - tworzących baseny sedymentacyjne. Kotliny stanowiły jednak także drogę odpływu wód proglacjalnych i ekstraglacjalnych - płynących z gór. Przepływ wód rzecznych powodował w kilku cyklach erozję i akumulację osadów. W ten sposób powstawały systemy teras i przedgórskich stożków napływowych. Wśród czynników morfotwórczych odgrywających istotną rolę w modelowaniu rzeźby kotlin należy wymienić także procesy eoliczne, z którymi związane jest powstanie pokryw lessowych (Dwucet 1986, Jersak 1991, Jary 1996) oraz form piaszczystych (wydm, niecek deflacyjnych, pól eolicznych piasków pokrywowych) (Waga 1994, Dulias 2002).

Według J. Lewandowskiego (2015) większa część Kotliny Oświęcimskiej nie została przykryta lądolodem Odry. Rozciągłość i morfologia Kotliny Raciborsko-Oświęcimskiej sprzyjała jednakże oscylacjom jego czoła i predysponowała kierunki odpływu olbrzymiej ilości wód roztopowych, które mogły rozmywać formy i osady świadczące o dalekim zasięgu lądolodu. W Kotlinie Raciborskiej widoczne są także poziomy zasypania fluwioglacjalnego z okresu degradacji lądolodu odrzańskiego i organizacji odpływu wód w kierunku zachodnim i północno-zachodnim (Karaś-Brzozowska 1963, Waga 1994).

Rzeźba polodowcowa i wodnolodowcowa wykształcona w okresie zlodowacenia odrzańskiego była przemodelowywana przez procesy peryglacjalne i rzeczne. Wyraźniej świadectwa tych procesów są zapisane w postaci głęboko wciętych dolin dorzecza Odry, ponieważ na obszarze dorzecza górnej Wisły w Kotlinie Oświęcimskiej formy i serie osadów wieku warciańskiego są pogrzebane pod osadami młodszymi (Niedziałkowska i in. 1985, Waga 1992).

Rozległe terasy rzeczne powstały w pełni vistulianu z materiału, który został wskutek procesów denudacyjnych przemieszczony z górnych części zlewni Odry i Wisły. Na przedpolu Karpat powstały stożki napływowe, z których największy jest stożek Wisły rozciągający się poniżej Ustronia (Gilot i in. 1982, Niedziałkowska i in. 1985). W okresie tym na Płaskowyżu Rybnickim oraz na Wysoczyznach Przykarpackich akumulowane były również lessy (Dwucet 1986, Jersak 1991). 
We współczesnej rzeźbie terenu wyróżniają się ponadto dwa zespoły form z późnego vistulianu. Pierwszym z nich są wydmy oraz towarzyszące im niecki deflacyjne, a także równiny pokrywowych piasków eolicznych. Są one bardziej charakterystyczne dla Kotliny Raciborskiej (Waga 1994, 2009) niż dla Kotliny Oświęcimskiej, gdzie są słabiej wykształcone (np. w okolicach Żor i na Równinie Gostyni) (Dulias 2002, 2009). Drugi zespół form z późnego vistulianu powstał w wyniku erozji i ruchów masowych. W tym czasie dopływy Odry i Olzy rozcinające Płaskowyż Rybnicki, dno Bramy Bąkowskiej i Wysoczyznę Kończycką bardzo intensywnie erodowały wstecznie (Waga 2009). W sytuacji nieprzepuszczalnego podłoża (iły mioceńskie i poziomy glin morenowych) doprowadzało to na zboczach młodych dolin do intensywnego przemieszczania gruntu przesyconego wodą. Podobne procesy rozwijały się na pozostałych Wysoczyznach Przykarpackich.

Później przez wielolecia na Płaskowyżu Rybnickim i na Wysoczyźnie Gaszowickiej powstawała gęsta sieć parowów i wądołów. Podobnie działo się w obrębie wysokiego, zachodniego zbocza doliny Odry (Płaskowyż Głubczycki). Mimo dużego urozmaicenia rzeźby na tych obszarach i gęstej sieci parowów - maksymalnie do $5 \mathrm{~km} \cdot \mathrm{km}^{-2}$ w okolicach Wodzisławia Śląskiego i Świerklan (Dwucet 1986) oraz do $4 \mathrm{~km} \cdot \mathrm{km}^{-2}$ na Płaskowyżu Głubczyckim (Jary 1996) - wąwozy występują tam bardzo rzadko.

O ile pogłębienie dolin z dorzecza Odry, takich jak Nacyna, Lesznica, Bierawka, Kłodnica, sięga w Kotlinie Raciborsko-Oświęcimskiej kilku metrów (Dwucet 1986), to doliny rzeczne w dorzeczu Wisły, takie jak Pszczynka czy Korzenica, noszą słabe ślady odmłodzenia holoceńskiego - są pogłębione do kilkudziesięciu centymetrów. W holocenie obserwuje się ponadto aktywność osuwiskową na stokach, co w znacznym stopniu było, obok erozji, stymulowane przez działalność człowieka, głównie na obszarach lessowych - rolnictwo neolityczne, średniowieczne i okresu nowożytnego oraz wylesianie (Klimek 2007).

O warunkach klimatycznych Kotliny Raciborsko-Oświęcimskiej decyduje w znacznym stopniu jej położenie w sąsiedztwie zachodniej części łuku Karpat i masywu Sudetów oraz bliskość Bramy Morawskiej, umożliwiającej częsty napływ mas powietrza z południowego zachodu i południowego wschodu. Kotlina Raciborsko-Oświęcimska należy do najcieplejszych regionów w Polsce.

W rozkładzie kierunków wiatru w Kotlinie Oświęcimskiej notowana jest dominacja wiatru południowo-zachodniego $(22,7 \%)$, co jest związane $z$ orientacją geograficzną doliny górnej Wisły. Na pozostałym obszarze kotliny dominują wiatry z sektora SW i zachodniego. Wymiana powietrza w Kotlinie Raciborskiej następuje w kierunku południkowym dzięki dolinie Odry (Kruczała 2000). Bardzo słabo przewietrzane są główne doliny lessowe w południowej części Płaskowyżu Rybnickiego (Radosz 2007). Średnia roczna suma opadów wynosi od 600-700 mm w Kotlinie Raciborskiej do 700-800 mm w Kotlinie Oświęcimskiej (Kruczała 2000, Serwis IMGW-BIP Klimat Polski).

W kontekście takich uwarunkowań fizycznogeograficznych istotne znaczenie dla współczesnego modelowania rzeźby ma pokrycie terenu i sposób jego 
użytkowania. Znaczna część Kotliny Raciborsko-Oświęcimskiej jest wykorzystywana rolniczo jako dobrej jakości grunty orne i kształtowana przez procesy geomorfologiczne $\mathrm{w}$ rytm morfogenetycznych pór roku. Z punktu widzenia przebiegu procesów erozyjno-denudacyjnych podkreślić należy istotne zmiany pokrycia i użytkowania terenu w ostatnich 100-200 latach. W niektórych małych zlewniach (np. Ruptawki) tereny zabudowane zajmują ponad 60\% ich powierzchni, $\mathrm{w}$ innych $\mathrm{w}$ miejsce pól pojawiły się rozległe formy antropogeniczne, np. w zlewni Dębinki zwałowiska i zalewiska w nieckach osiadania zajmują niemal 1/4 jej powierzchni (Dulias 2008a).

\subsubsection{Współczesne procesy geomorfologiczne - uwarunkowania i skutki}

Współczesne procesy geomorfologiczne na obszarze Kotliny Raciborsko-Oświęcimskiej zachodzą w warunkach środowiska przyrodniczego wyraźnie zmienionego wskutek długotrwałej i intensywnej działalności człowieka. Jednym z głównych czynników naturalnych wpływających na charakter, przebieg i intensywność tych procesów są cechy litologiczne podłoża - szerokie rozprzestrzenienie utworów drobnoziarnistych - lessów, glin i deluwiów pyłowych, czyli utworów podatnych na procesy erozji wodnej, a po przesuszeniu - także erozji wietrznej. Zróżnicowana przepuszczalność utworów podłoża (mioceńskich iłów, czwartorzędowych piasków i żwirów) w połączeniu z dużym nachyleniem stoków stwarza warunki do zachodzenia ruchów masowych. Współczesnemu spłukiwaniu i erozji linijnej sprzyjają stosunki wysokościowe w obrębie płaskowyżów i wysoczyzn lessowych (szczególnie wysokie wyniesienie Płaskowyżu Rybnickiego ponad dna dolin) oraz rozczłonkowanie ich stoków dolinami plejstoceńskimi i holoceńskimi. Natężenie erozji w odrzańskiej i wiślańskiej części kotliny jest zróżnicowane ze względu na duże różnice w położeniu baz erozyjnych Odry (pod Krapkowicami - $160 \mathrm{~m}$ n.p.m.) i Wisły (pod Zatorem - 220 m n.p.m.). Charakter i przebieg współczesnych procesów geomorfologicznych jest także uwarunkowany różnorodną działalnością człowieka oraz utworzonymi z jego bezpośrednim i/lub pośrednim udziałem formami rzeźby terenu.

\subsubsection{Procesy stokowe}

Stoki na obszarze Kotliny Raciborsko-Oświęcimskiej są zróżnicowane pod względem budowy geologicznej, cech morfometrycznych, stosunków wodnych oraz rodzaju pokrywy roślinnej i sposobu użytkowania. Modelowane są przez różne procesy stokowe, $z$ różną intensywnością oraz częstotliwością zależną od czynników naturalnych i antropogenicznych.

W przekształcaniu stoków istotną rolę odgrywa spłukiwanie. Przyczyną powstawania bardzo świeżych i głębokich rozcięć erozyjnych na obszarach rolniczych są nawalne deszcze, powodujące również spłukiwanie materiału glebowego. W ostatnich 20-30 latach wraz ze zmianą sposobu użytkowania gruntów ornych, tj. wprowadzeniem wielkoobszarowych upraw monokulturowych, zaorywaniem dróg i miedz, na glebach o wyższych klasach bonitacyjnych, w okresach 
wczesnowiosennym i jesiennym dochodzi do wzmożonego spłukiwania i redepozycji materiału, m.in. w nieckach na polach i w rowach odwodnieniowych. U wylotów dolin nieckowatych i bruzd erozyjnych tworzą się stożki napływowe. O intensywności tych procesów może świadczyć przykład z Pielgrzymowic, gdzie wiele rowów melioracyjnych zostało zupełnie zamulonych - w $1996 \mathrm{r}$. wymagały oczyszczenia na długości aż 8,5 km (Dulias, Pełka-Gościniak 2002). Podobne zjawisko wystąpiło 20 lat później w Lyskach.

Spektakularne przykłady rozwoju form erozji linijnej występują w Miejscu Odrzańskim (Wieland 1988). W obrębie lewego, stromego zbocza doliny Odry można obserwować różne stadia wykształcenia form, od dojrzałego parowu głównego do młodych, bocznych wąwozów o pionowych, wysokich (do $7 \mathrm{~m}$ ) ścianach. System ten rozwinął się przy wydatnym udziale człowieka (parów - z przekształcenia rozwiniętego $\mathrm{w}$ okresie prahistorycznym wąwozu kołowego, zaś wąwozy z zapoczątkowanego w latach 30 . XX w. układu odprowadzania wody deszczowej i roztopowej z rowów przydrożnych). Ściany bocznych wąwozów w Miejscu Odrzańskim są intensywnie modelowane przez procesy obrywania, osuwania i sufozji, a ich dna i podstawy ścian okresowo rozcinane przez erozję linijną (Wieland 1988).

W wielu małych zlewniach Kotliny Raciborsko-Oświęcimskiej będących w zasięgu osiadań górniczych powierzchnia odwadniana przez spływ powierzchniowy wyraźnie się zmniejszyła $z$ powodu powstania zagłębień bezodpływowych i zmian w przebiegu działów wodnych (Czaja 1988, Dulias 2013). Skrajnym przykładem jest zlewnia Dębinki, w której niemal połowa powierzchni $\left(4 \mathrm{~km}^{2}\right)$ stała się bezodpływowa (Dulias 2008a). Zmiany te są na tyle duże, że zmodyfikowały przebieg procesów erozyjno-denudacyjnych.

W większości zlewni górniczych potencjał erozyjny podsystemu stokowego został wyraźnie zwiększony wskutek zmian nachylenia stoków, a mianowicie zmniejszenia udziału terenów równinnych (np. w zlewni Marklówki na Płaskowyżu Rybnickim o ponad 12\%, a w zlewni Cienkiej na Wysoczyźnie Rachowickiej o ponad 20\%) oraz zwiększenia udziału stoków o nachyleniu $1-3^{\circ}$, a w miejscach występowania zwałowisk także większym, powyżej $9^{\circ}$ (np. w zlewni Radlińskiego Potoku o ponad 4\%) (Dulias 2013).

Stoki w kotlinie są też modelowane przez procesy osuwiskowe, zachodzące głównie na Płaskowyżu Rybnickim i Wysoczyźnie Kończyckiej. Naliczono tu niemal 750 różnie zachowanych i mających różną wielkość osuwisk, co sprawia, że pod względem ich liczebności obszar ten zajmuje trzecie miejsce w Polsce, po Karpatach i Sudetach (Waga, Fajer 2021a). Najwięcej form osuwiskowych występuje w pasie od okolic Kończyc, Zebrzydowic, Jastrzębia-Zdroju, Wodzisławia Śląskiego, Lubomii, Syrynii do Raciborza Obory. Pojawiają się one też na stromym, zachodnim zboczu doliny Odry między Miedonią i Podlesiem.

Dla rozwoju osuwisk na Płaskowyżu Rybnickim istotne są dwa czynniki: obecność wysokich (do $100 \mathrm{~m}$ ) krawędzi morfologicznych górujących nad doliną Odry i Olzy, rozciętych głębokimi dolinami erozyjnymi oraz budowa geologiczna - występowanie nieprzepuszczalnych warstw iłów i glin. K. Dwucet (1986) 
stwierdziła, że formy osuwiskowe powstały głównie wskutek okresowego zawodnienia spągowych partii utworów lessopodobnych. Silne natężenie osuwania gruntów było odnotowane w 1977 r. w okolicach Pogrzebienia i Syrynii (Puchejda 1978), a wiązało się ono $z$ bardzo wysokimi opadami zimowymi i letnimi w 1977 r. W strefie tej zbocze doliny Odry, eksponowane ku zachodowi, otrzymuje wyższe ilości opadów niż wierzchowina Płaskowyżu Rybnickiego.

Osunięcia ziemi wywołane czynnikami antropogenicznymi obserwowano też w okolicy Świerklan, w Rybniku czy w Jastrzębiu-Zdroju (Grzesiak, Trzepierczyński 2014). Część procesów osuwiskowych została wywołana czynnikami górniczymi - zmniejszeniem spójności gruntu i zmianami nachylenia stoków na obszarach deformacji górniczych, ewentualnie wstrząsami indukowanymi pracami górniczymi. Badania na Płaskowyżu Rybnickim, na obszarze tzw. Wzgórz Pszowskich (Krajewski i in. 1968), wykazały, że duża liczba zerw i osuwisk na ich stromych stokach opadających do doliny Syrynki jest uwarunkowana nie tylko obecnością w podłożu mioceńskich iłów, ale także działalnością górniczą kopalni „Anna”. W okolicach Jastrzębia-Zdroju zinwentaryzowano 51 osuwisk, w większości powstałych na skarpach parowów i zboczach małych dolinek z niewielkimi ciekami, najczęściej o nachyleniu 35-40 spoczywających na utworach piaszczysto-żwirowych. Niemal $60 \%$ tych osuwisk powstało $w$ granicach wpływów górniczych, w sąsiedztwie progów i uskoków terenowych o genezie niewątpliwie związanej z eksploatacją podziemną (Krajewski $\mathrm{i}$ in. 1982). I. Chmielowska (1995) podaje przykład osuwisk z obszaru dawnej kopalni „1 Maja”. W 1994 r. powstały tu liczne, drobne zerwy w bocznych dolinkach na lewym brzegu Lesznicy, na obszarze zbudowanym z plejstoceńskich utworów gliniastych, podścielonych iłami miocenu. Zerwy wytworzyły się po przejściu frontu eksploatacji. Mimo że główną rolę w formowaniu się osuwisk odgrywają naturalne predyspozycje terenu, to działalność górnicza jest czynnikiem aktywizującym procesy osuwiskowe. Duże znaczenie ma tu zmniejszenie ogólnej spójności gruntu - w strefie rozciągania niecki osiadania grunty ulegają rozluźnieniu i w konsekwencji powstają szczeliny, których istnienie jest czynnikiem przyspieszającym rozwój osuwisk. W 2005 r. na obszarze kopalni „Rydułtowy" bardzo silny wstrząs górotworu spowodował poważne szkody w zabudowie i infrastrukturze. W przeszłości tąpnięcia mogły być przyczyną uruchamiania osuwisk, szczególnie na terenach, gdzie występują grunty kurzawkowe.

\subsubsection{Procesy fluwialne}

Kotlina Raciborsko-Oświęcimska odwadniana jest przez górną Odrę i Wisłę, które wraz z dopływami tworzą stosunkowo gęstą sieć rzeczną. Obie te rzeki charakteryzuje $\mathrm{w}$ obrębie kotliny podobny reżim wezbrań wywołanych intensywnymi opadami w miesiącach letnich na ich obszarach źródłowych.

W XIX w. rozpoczęto powszechną regulację koryt obu rzek. Skrócono ich bieg, umocniono brzegi opaskami kamiennymi i ostrogami, ukierunkowano nurt (Łajczak 1995). W wyniku regulacji koryto Odry w obrębie kotliny zostało skrócone

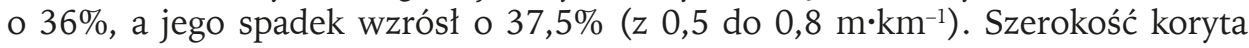


w efekcie prac regulacyjnych uległa zmniejszeniu o około $70 \mathrm{~m}$ i obecnie wynosi średnio $60 \mathrm{~m}$. Przed regulacją szerokość równiny zalewowej Odry, zatapianej podczas dużych wezbrań, wynosiła około $4-5 \mathrm{~km}$. Konstrukcja wałów przeciwpowodziowych spowodowała ograniczenie strefy zatapiania wezbraniowego nawet do 200 m (Czajka 2007). Prace regulacyjne przeprowadzone na odcinku Wisły w obrębie kotliny przyczyniły się do jego skrócenia o $15,4 \%$, a spadek wzrósł o 22,5\%. Szerokość koryta zmniejszyła się o około 40 do $70 \mathrm{~m}$ i wynosi obecnie od 20 do 50 m (Czajka 2007).

Osłabienie retencji i szybki spływ wód opadowych wynikające z deforestacji zlewni spowodowało intensywną erozję gleb i wzrost dostawy drobnego materiału do koryt rzecznych. W rzekach wzrosła amplituda wahań stanów wody i zwiększyła się gwałtowność krótkich fal wezbraniowych. Na odcinku pomiędzy Chałupkami a Miedonią w latach 1978-1990 wody Odry niosły rocznie około 277500 ton materiału, $\mathrm{z}$ czego $\mathrm{w}$ postaci osadów pozakorytowych deponowane było około 195 tys. ton, co daje depozycję 5500 ton $\cdot \mathrm{km}^{-1} \cdot \mathrm{a}^{-1}$. W końcu lat 80 . $\mathrm{XX}$ w. depozycja materiału unoszonego była mniej intensywna a przyczyną tego była zmniejszona w tym czasie częstotliwość dużych wezbrań.

Średnia łączna dostawa materiału unoszonego przez Wisłę i jej dopływy w obrębie Kotliny Oświęcimskiej wynosiła w drugiej połowie XX w. około 570000 ton ${ }^{-1}{ }^{-1}$, z czego dalej wynoszonych było około 450000 ton rocznie. W ciągu roku w strefie międzywala Wisły depozycji ulegało średnio 120000 ton materiału (średnio 20950 ton $\cdot \mathrm{km}^{-1} \cdot \mathrm{a}^{-1}$ ), czyli czterokrotnie więcej niż w badanym odcinku Odry. Znaczna ilość transportowanego przez górną Odrę i Wisłę materiału jest deponowana na równinie zalewowej podczas największych wezbrań. Na Górnej Odrze stany wody ponadpełnokorytowe występują ze średnią częstotliwością od 0 do 4 zdarzeń $\mathrm{a}^{-1}$. Natomiast średni czas łącznego trwania zatopienia równiny zalewowej w obrębie międzywala Górnej Odry wynosi od 1 do 13 dni $\cdot^{-1}$. Na Wiśle stany wody ponadpełnokorytowe występują ze średnią częstotliwością od 0 do 3 zdarzeń$\cdot \mathrm{a}^{-1}$ (Bieruń Nowy) do 5 zdarzeń $\mathrm{a}^{-1}$ (Dwory/Gromiec). Największą częstotliwość takich stanów wody stwierdzono w latach 60 . XX w., w połowie lat 70 . XX w. i po 1995 r. Średni czas łącznego trwania zatopienia równiny zalewowej w międzywalu Wisły wynosi od 2,7 dni $\cdot \mathrm{a}^{-1}$ (Bieruń Nowy) do $1,7 \mathrm{dni} \cdot \mathrm{a}^{-1}$ (Dwory/Gromiec).

Depozycja osadów zachodzi przede wszystkim w strefie przykorytowej, powodując pionowy przyrost mad (Ciszewski, Czajka 2009). Osady te to przede wszystkim piaski przewarstwiane materiałem drobniejszym z dużą zawartością materii organicznej. Średnie tempo przyrostu pionowego osadów waha się od 1,7 do $6 \mathrm{~cm} \cdot \mathrm{a}^{-1}$. Przeciętna miąższość deponowanych osadów jest mniejsza na Wiśle niż na Odrze, co może wynikać z faktu występowania na Odrze większych przepływów maksymalnych, podczas których zachodzi depozycja pozakorytowa. Przyrost wysokości brzegów Odry jest lokalnie równoważony jednoczesnym jego zwężeniem i spłyceniem, przeciwnie do koryta Wisły, gdzie zwężaniu koryta towarzyszy jego pogłębianie (Czajka 2007).

Antropopresja zaznaczyła się nie tylko w zmianach ilościowych, ale również jakościowych osadów. Zmianie uległ skład chemiczny osadów w dolinach rzek 
sąsiadujących $z$ terenami uprzemysłowionymi i zurbanizowanymi. W aluwiach Odry i Wisły zmiany te rozpoczęły się w połowie XVIII w. wraz z rozpoczęciem eksploatacji węgla kamiennego na Górnym Śląsku i w rejonie karwińsko-ostrawskim. Począwszy od tego czasu obecny jest w aluwiach Odry i Wisły miał węglowy oraz metale ciężkie (Ciszewski, Czajka 2009).

Duża dostawa materiału niesionego przez rzeki już od średniowiecza stanowiła poważny problem w utrzymaniu zbiorników zaporowych. Zamulanie dużego zbiornika wodnego, jakim jest Zbiornik Goczałkowicki, spowodowało, że w ciągu 19 lat osiągnął on głębokość krytyczną. Od około 1975 r. falowanie powoduje erodowanie stropu osadów dennych. Naprzemienność procesów zamulania i erodowania sprawia, że od wielu lat objętość misy zbiornika wodnego nie ulega większym zmianom (Łajczak 2003).

W zlewniach Rudy na Płaskowyżu Rybnickim i Bierawki w Niecce Kozielskiej zaznaczyły się dwie fazy antropopresji, starsza - średniowieczna, związana z intensywną kolonizacją rolniczą i erozją gleb, oraz młodsza, związana z górnictwem węglowym i rozwojem przemysłu metalurgicznego w czasie ostatnich 200 lat. Materiał pochodzący ze średniowiecznej erozji gleb został zdeponowany w dnach dolinek rozcinających wysoczyzny lessowe, a następnie w dnach dopływów Odry. Aluwia te budują m.in. współczesny nadzalewowy poziom dna doliny Rudy (Klimek 1995). Faza ta zapisała się w cechach strukturalnych aluwiów i częściowo także w ich cechach geochemicznych (dwukrotny wzrost koncentracji Zn). Młodsza faza antropopresji charakteryzowała się ponadto wzrostem o rząd wielkości koncentracji metali ciężkich $(\mathrm{Cd}$ i $\mathrm{Pb})$ w osadach budujących niższy stopień terasowy i we współcześnie formowanych łachach piaszczystych (Klimek 1995, 1996, Klimek, Woskowicz-Ślęzak 2016). Są to w przewadze warstwowane piaski średnio- i drobnoziarniste przewarstwione ciemnymi mułami z dużym nagromadzeniem w nich miału węglowego. Wskazuje to na ich osadzanie po rozpoczęciu górnictwa węglowego na obszarze rybnickim, zapoczątkowanym na przełomie XVIII/XIX w. (Klimek 1995, 1996).

Stosunkowo intensywna gospodarka prowadzona od średniowiecza na obszarze Kotliny Raciborsko-Oświęcimskiej spowodowała, że niemal wszystkie koryta rzeczne zostały na tym terenie przebudowane. Działaniom tym opiera się jedynie Soła na odcinku od Czańca po Oświęcim (Woskowicz-Ślęzak, Ślęzak 2012, Woskowicz-Ślęzak 2013). Zaś krótkie odcinki koryta Rudy (między Stodołami i Paprocią oraz Rudą Kozielską i Górną Huta), a także Bierawki (w okolicach Goszyc) mają bieg naturalny lub zrenaturyzowany. Wyjątkowym zjawiskiem jest naturalizacja odcinków dawnych sztucznych kanałów Suminy (obecnego dopływu Rudy). W przypadku przełomów w Suminie i Małej Nędzy kanały uległy tak dużym przekształceniom, że dziś są najbardziej naturalnie wyglądającymi fragmentami doliny rzecznej (Fajer 2018).

W Kotlinie Raciborsko-Oświęcimskiej na uwagę zasługują doliny mniejszych rzek będące $\mathrm{w}$ zasięgu bezpośrednich i pośrednich wpływów górnictwa węglowego. Przekształcenia w ich korytach obejmują zmiany cech fizycznych samego koryta (długość, spadek, bieg) oraz zmiany w ilości transportowanej w korycie 
wody i materii. Część koryt, oprócz umocnienia brzegów kostką brukową lub faszyną, została ujęta w kamienno-betonowe żłoby, np. Potok Goławiecki, Gostynia, Potok Tyski (ryc. 6.2). W wielu korytach utworzono betonowe lub kamienne stopnie wodne dla redukcji spadku podłużnego, np. w korycie Szotkówki czy Kłodnicy. Na obszarach osiadań górniczych liczne koryta zostały obwałowane na znacznej długości, np. Mlecznej - 32 km, Gostyni - 28 km (Dulias 2013). Na terenach o mało urozmaiconej rzeźbie, np. w dolnych odcinkach Pszczynki i Korzenicy, obniżenie powierzchni o około $2,5 \mathrm{~m}$ spowodowało konieczność przełożenia ponadpółkilometrowych odcinków obu rzek i obwałowania ich na długości $2 \mathrm{~km}$. Kilkumetrowej wysokości obwałowania koryta Szotkówki utworzone pod koniec XX w. w ciągu 10 lat znalazły się pod taflą zalewiska w niecce osiadania (Dulias 2016). Świadczy to o dużej, ponadprzeciętnej dynamice procesów geomorfologicznych w dolinach mniejszych rzek kotliny.

W wyniku wymuszonych skutkami górnictwa zabiegów hydrotechnicznych część koryt rzecznych została skrócona, np. koryto Nacyny o 1,2 km, a Mlecznej o 1,5 km. Wiele rzek jest jednak obecnie dłuższych, np. Knurówka, Potok Szczygłowicki czy Marklówka, co jest konsekwencją wydłużenia ich górnych odcinków objętych osiadaniem górniczym (przecięcie poziomu wodonośnego przez obniżającą się powierzchnię i wypływ wody).

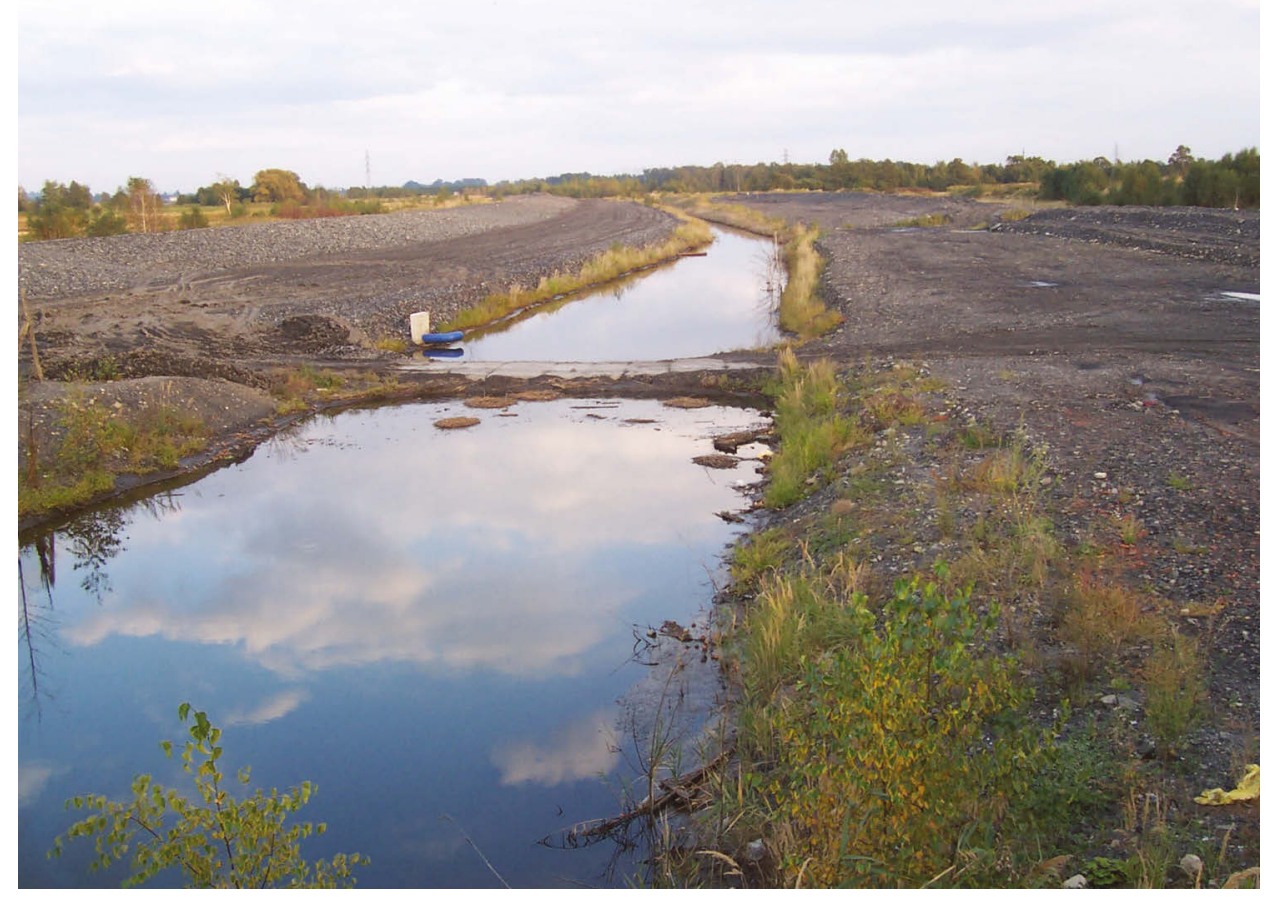

Ryc. 6.2. Przykład terasy zalewowej nadbudowanej skałą płonną i ograniczonej hałdowałami w dolinie Potoku Goławieckiego, Kotlina Oświęcimska (fot. R. Dulias, 2008) 
Z geomorfologicznego punktu widzenia jedną z najważniejszych zmian w dolinach opisywanych rzek są zmiany bazy erozyjnej oraz spadków dna i kształtów profilów podłużnych. Obniżenia bazy erozyjnej są związane z osiadaniem obejmującym ujścia rzek. Spektakularnym przykładem jest Cienka (dopływ Kłodnicy), dla której stwierdzono obniżenie bazy o 13,2 m (Dulias 2013). Obniżenia bazy erozyjnej rzędu 5-6 m wykazano $\mathrm{m}$.in. dla wielu małych cieków w dorzeczu Odry. Spośród badanych rzek jedynie dla Nacyny stwierdzono podwyższenie bazy erozyjnej o 4 m, co było związane z utworzeniem Zalewu Rybnickiego. Obniżenie bazy erozyjnej powoduje wzrost tempa wcinania się rzek, czego przykłady podają A.T. Jankowski (1986), J. Wach (1987), R. Dulias (2013, 2016).

Deformacje powierzchni obszarów górniczych powodują odkształcenia dolin rzecznych skutkujące zmianami ich spadku - zwiększeniem, zmniejszeniem, a także odwróceniem. Zwiększenie spadku prowadzi do przyspieszenia procesów erozyjnych, szczególnie gdy dotyczy dolnego, ujściowego odcinka rzeki (Jankowski 1986, Dulias 2013). Konsekwencją zmniejszenia spadku jest zmniejszenie prędkości wody i wzmożona akumulacja niesionego materiału - koryto ulega spłyceniu, może też dojść do spiętrzenia wody i rozlania cieku na obszar doliny. Spłaszczenie profilu podłużnego rzek w połączeniu ze wzrostem ilości materiału niesionego przez rzeki (zwłaszcza zawiesiny) przyspiesza nabudowywanie teras zalewowych (Wach 1987). Przejście eksploatacji pod korytem cieku, zwłaszcza w odcinku środkowym, może też spowodować odwrócenie spadku i powstanie zalewiska ze zwierciadłem wody sięgającym rzędnej tego odwrócenia (Mackiewicz i in. 1979, Pozzi i in. 2008). Są to baseny sedymentacyjne dla osadów niesionych przez rzeki (Wach 1987, Dulias 2013). Wiele rzek będących w zasięgu dzialalności górniczej i różnych zabiegów hydrotechnicznych ma więc obecnie niewyrównane profile podłużne - naprzemiennie występują długie odcinki o małym spadku i krótkie odcinki z dużym spadkiem (Jankowski 1986, Wach 1987, Dulias 2008b, 2011, 2013). Znaczne zwiększenie spadku odnotowano dla rzek małych i średnich, np. Radlińskiego Potoku $(+4,4 \%$ o $)$ czy Jordanka $(+2,5 \%$ o $)$ (Dulias 2013).

Charakterystyczną cechą wielu rzek Kotliny jest ponadnormatywne zanieczyszczenie wód zawiesiną (Mackiewicz i in. 1979, Nocoń, Kostecki 2005, Działoszyńska-Wawrzkiewicz 2008). Głównym składnikiem zawiesin jest pył węglowy. Zwiększona ilość materiału niesionego przez rzeki przyspiesza nabudowywanie teras zalewowych, często zazębiających się z materiałem hałdowałów sypanych wzdłuż koryt rzecznych (Wach 1987) (ryc. 6.2). Podczas wysokich stanów wód namuły antropogeniczne $z$ den i brzegów są powtórnie unoszone i redeponowane. Dużym zanieczyszczeniem mułem węglowym odznaczają się wody Nacyny w latach 70. XX w. jego zawartość w wodzie dochodziła nawet do $6000 \mathrm{mg}^{\circ} \mathrm{dm}^{-3}$ (Mackiewicz i in. 1979). Ścieki z dużą ilością zawiesin zamulają m.in. koryta - Bierawki, Szotkówki, Potoku z Gogołowej i Potoku Goławieckiego. W ostatnich dwóch dekadach obserwuje się systematyczną poprawę sytuacji ekologicznej regionu, co ma odzwierciedlenie w zmniejszonej antropopresji, w tym na środowisko wodne. Przykładowo w latach 1998-2004 we wszystkich stanowiskach 
pomiarowych wzdłuż Kłodnicy wyraźnie zmalały maksymalne stężenia zawiesiny m.in. w Gliwicach Sośnicy z 5562 do $1433 \mathrm{mg}^{*} \mathrm{dm}^{-3}$, a w Gliwicach Łabędach z 4242 do $131 \mathrm{mg} \cdot \mathrm{dm}^{-3}$ (Nocoń, Kostecki 2005).

\subsubsection{Współczesne procesy eoliczne}

Mimo znacznego udziału procesów eolicznych w kszałtowaniu rzeźby Kotliny Raciborsko-Oświęcimskiej u schyłku zimnego piętra wisły, w obecnych uwarunkowaniach klimatycznych odgrywają one mniejszą rolę. J. Wojtanowicz (2010) zaliczył ten region do obszarów o zróżnicowanym natężeniu współczesnych procesów eolicznych - od bardzo silnego (500-1000 $\left.\mathrm{t} \cdot \mathrm{km}^{-2}\right)$ na wierzchowinach południowej części Płaskowyżu Rybnickiego do słabego (50-200 t• $\left.\mathrm{km}^{-2}\right)$ na zalesionych terenach Niecki Kozielskiej, Wysoczyzny Golejowskiej i Doliny Wisły. Warunki anemologiczne dla rozwoju procesów eolicznych są najmniej korzystne w Kotlinie Oświęcimskiej w związku z dominacją wiatrów słabych natomiast na pozostałym obszarze są potencjalnie bardziej sprzyjające. Wpływ na zwiększenie intensywność deflacji może mieć ukierunkowanie wiatrów z sektora południowo-zachodniego przez Bramę Morawską.

Przejawy procesów eolicznych obserwowano w kopalni piasków podsadzkowych w Kotlarni, ale były to jedynie niewielkie pola riplemarków wiatrowych i małe cienie piaszczyste oraz powierzchnie bruków deflacyjnych. Także na prawie 10000 ha pożarzyska leśnego (1992 r.) w okolicach Kuźni Raciborskiej dawne formy wydmowe nie zostały objęte znaczącymi wtórnymi procesami eolicznymi. Wypalony teren został już w następnym sezonie wegetacyjnym zajęty przez roślinność $z$ dominacją trzcinnika piaskowego, która utrwaliła powierzchnie i zapobiegła przewiewaniu piasku (Waga, inf. ustna).

Bardziej znaczącą rolę odgrywają procesy erozji eolicznej na terenach użytkowanych rolniczo $\mathrm{w}$ czasie prac agrotechnicznych w sezonie wiosennym i jesiennym. Obserwowane są także intensywne procesy wywiewania pyłu ze składowisk skały płonnej górnictwa węgla kamiennego, szczególnie z dróg technologicznych.

\subsubsection{Procesy i formy antropogeniczne}

Obszar Kotliny Raciborsko-Oświęcimskiej jest w zasięgu antropopresji od neolitu, lecz dopiero $\mathrm{w}$ ostatnich kilkuset latach ma ona znaczący wpływ na przebieg współczesnych procesów geomorfologicznych i ukształtowanie powierzchni terenu.

Ogromny wpływ na ewolucję rzeźby Kotliny Raciborsko-Oświęcimskiej wywarło odkrywkowe i podziemne górnictwo różnych surowców. Kluczowe znaczenie miała eksploatacja węgla kamiennego, zdecydowanie mniejsze, ale także istotne - piasków podsadzkowych, kruszyw mineralnych, surowców ilastych oraz rud żelaza.

W zlewniach Rudy i Bierawki występują liczne, zróżnicowane pod względem wielkości i kształtu kopce i leje, będące śladem dawnego górnictwa rud żelaza (ryc. 6.3). Trudnili się tym już cystersi od XIII-XIV w., a koniec eksploatacji nastąpił prawdopodobnie w połowie XIX w. (Grygierczyk i in. 1997, Fajer, Waga 


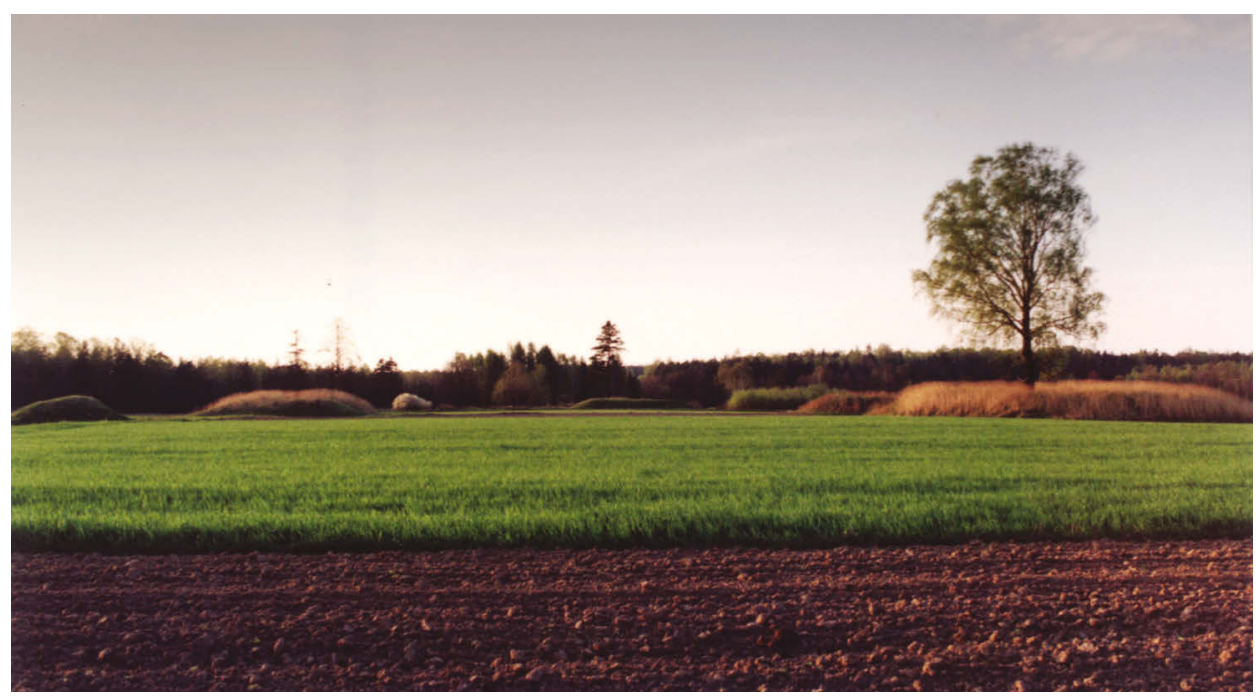

Ryc. 6.3. Hałdy wokół szybów eksploatacyjnych mioceńskich syderytów, Stanica-Górniki (fot. J.M. Waga)

2002). Formy poeksploatacyjne położone wśród lasów i nieużytków są dobrze zachowane, łącznie z zarysem niecek z osiadania.

Szerokie rozprzestrzenienie różnowiekowych skał ilastych sprzyjało ich górniczemu pozyskiwaniu już od średniowiecza, ale z największym nasileniem w XIX w. oraz w pierwszej połowie XX w. na potrzeby licznych cegielni. Wyrobiska po tych surowcach ilastych są liczne, ale występują w dużym rozproszeniu - najwięcej jest ich na Wysoczyźnie Rachowickiej (8, Dulias 2013).

W granicach kotliny eksploatowane są złoża kruszyw naturalnych, w większości w dużych dolinach rzecznych - Odry, Wisły, Soły, Olzy. W ostatnich latach największe wydobycie prowadzono ze złoża Przecieszyn w dolinie Soły $(0,56 \mathrm{mln}$ ton), Gardawice na Wysoczyźnie Golejowskiej (500 000 ton), a także Racibórz Roszków i Lubomia III w dolinie Odry.

Duże znaczenie w przekształcaniu rzeźby kotliny miała eksploatacja piasków podsadzkowych. Do największych wyrobisk należą: Kotlarnia, Dzierżno Duże (objętość wyeksploatowanego materiału - $\left.111 \mathrm{mln} \mathrm{m}^{3}\right)$, Dzierżno Małe $\left(14 \mathrm{mln} \mathrm{m}^{3}\right)$, Pławniowice i wchodzące częściowo w obręb kotliny - Dziećkowice $\left(64,6 \mathrm{mln} \mathrm{m} \mathrm{m}^{3}\right)$ (Dulias 2013). Głębokość większych form wynosiła średnio 15-20 m. W wielu piaskowniach składowano odpady górnictwa węglowego i z czasem zamieniły się w nadpoziomowe zwałowiska, przykładowo „Przezchlebie”. W licznych piaskowniach, w tym w największych, występują zbiorniki wodne - ich brzegi są modelowane przez procesy litoralne (brzegowe) (Rzętała 2003, Rzętała 2008).

Ogromny wpływ na zmiany ukształtowania powierzchni Kotliny Raciborsko-Oświęcimskiej miała i ma nadal eksploatacja węgla kamiennego. Zapoczątkowana jeszcze w końcu XVIII w., największą presję na rzeźbę wywarła w XX w., 
zwłaszcza w jego drugiej połowie. W granicach kotliny, według stanu na $1993 \mathrm{r}$. (przed zmianami strukturalnymi w górnictwie węglowym), znajdowały się obszary górnicze 26 kopalń w całości i 6 kopalń po części. W granicach kotliny wydobyto dotychczas około 3,5 mld ton węgla kamiennego (Dulias 2016). Powstały tu wielkie zwałowiska skały płonnej, osadniki, a przede wszystkim rozległe niecki osiadania. Obecność tych form wpłynęła modyfikująco na przebieg współczesnych procesów erozyjno-denudacyjnych, niezależnie od tego, że one same są przez te procesy modelowane.

Zwałowiska (hałdy) skały płonnej i odpadów przeróbczych należą do powszechniejszych form antropogenicznych na obszarze kotliny (Pełka, Pociecha 1991, Dulias 2013). Wybitnie wyróżniają się w rzeźbie Płaskowyżu Rybnickiego, gdzie jest ich 39 i zajmują łącznie powierzchnię prawie $9 \mathrm{~km}^{2}$. Formy te mają różne kształty. Starsze formy są najczęściej stożkowate, np. hałdy kopalni „Dębieńsko” na Wysoczyznach Przywyżynnych czy hałdy kopalni „Rydułtowy” na Płaskowyżu Rybnickim (Pełka-Gościniak, Szczypek 1997). Liczne zwałowiska mają kształt masywnych stoliw. Niektóre formy osiągają bardzo duże wysokości - za najwyższą jest uważana „Szarlota” na Płaskowyżu Rybnickim - 134 m (Gawor, Szmatłoch 2010). Wiele zwałowisk zajmuje bardzo dużą powierzchnię - największą pod tym względem jest „Smolnica” $\left(2,55 \mathrm{~km}^{2}\right)$ na Wysoczyźnie Wilczy (Dulias 2013).

Zwałowiska o dużej masie mogą przyczynić się, w wyniku nacisku na podłoże, do wyciskania gruntu u jego podstawy w formie nabrzmienia (wybrzuszenia, ondulacji). W Kotlinie Raciborsko-Oświęcimskiej proces ten występuje prawdopodobnie wokół około 20-25 zwałowisk utworzonych na podłożu mioceńskich iłów, plejstoceńskich glin i lessów (Dulias 2016). Zwałowiskiem, na którego przedpolu proces ten jest obserwowany od ponad 30 lat, jest zwał „Pochwacie” w granicach kopalni „Jastrzębie” (Jankowski 1986, Krokoszyński, Rybicki 2010, Dulias 2013).

Podziemna eksploatacja węgla kamiennego ujawnia się na powierzchni terenu w postaci deformacji ciągłych - niecek osiadania oraz deformacji nieciągłych - zapadlisk i form linijnych o charakterze szczelin i progów. Niecki osiadania na Płaskowyżu Rybnickim mają głębokość do 20-25 m (Dulias 2011), na Wysoczyźnie Rachowickiej - do kilkunastu metrów, a we wschodniej części Kotliny Oświęcimskiej - do $7 \mathrm{~m}$ (Dulias 2008b). Zapadliska powstawały głównie na Płaskowyżu Rybnickim (Palki 1981). Ze względu na stosunkowo niewielkie rozmiary (średnice do $20 \mathrm{~m}$, głębokość do $3 \mathrm{~m}$ ) większość form została zniwelowana.

Deformacje liniowe są szczególnie częste na Płaskowyżu Rybnickim. Progi i szczeliny, występują zazwyczaj równocześnie i ciągną się na długości kilkuset metrów (Janusz i in. 1982). Szerokości szczelin wynoszą od kilku milimetrów do około 0,6 m, a wysokość progów dochodzi do 0,8 m, rzadziej do 1,2 m. Liczne progi terenowe powstały na Wysoczyźnie Rachowickiej, na obszarze kopalni „Knurów” (Kruczkowski 1999).

Obniżenie powierzchni terenu na obszarze osiadań górniczych w połączeniu $z$ powstaniem wysokich zwałowisk i głębokich wyrobisk po eksploatacji 
powierzchniowej spowodowało zmiany cech morfometrycznych rzeźby - wysokości bezwzględnych i względnych oraz nachylenia stoków. Dla obszaru Kotliny Raciborsko-Oświęcimskiej wykazano istotne zmiany w powierzchni poszczególnych przedziałów wysokościowych - o prawie $21 \mathrm{~km}^{2}$ zmniejszyła się powierzchnia obszarów o wysokości 250-260 m n.p.m., natomiast powierzchnia obszarów położonych na wysokościach 220-230 i 230-240 m n.p.m. zwiększyła się odpowiednio o 11,6 i 13,4 km² (Dulias 2013). Z rozkładu zmian wysokości względnych na obszarze kotliny wynika, że generalnie rzeźba obszarów równinnych została urozmaicona, a silniej urzeźbionych złagodzona. Zmiany nachylenia stoków wyrażają się zmniejszeniem powierzchni terenów równinnych (o nachyleniu poniżej $1^{\circ}$ ) o prawie $68 \mathrm{~km}^{2}$ oraz zwiększeniem powierzchni stoków o nachyleniu powyżej $1^{\circ}$.

Ubytek mas skalnych z podłoża Kotliny Raciborsko-Oświęcimskiej jest związany niemal w całości z górnictwem węgla kamiennego, a wywołane nim zmiany rzeźby mają charakter regionalny, wielkopowierzchniowy. Skala ubytku jest tak duża, że nawet po jego rozłożeniu na cały, nawet niegórniczy obszar kotliny, daje to obniżenie (w zależności od zastosowanej metody obliczenia) średnio o 1,92,1 m (Dulias 2013).

Charakterystyczną cechą rzeźby kotliny są misy licznych zbiorników wodnych, w tym kilku dużych (Dzierżno Duże i Małe, Zbiornik Goczałkowicki, Zbiornik Rybnicki, Paprocany, Łąka, część zbiornika Dziećkowice) i wielu mniejszych o różnej genezie - w nieckach osiadania, poeksploatacyjnych, hodowlanych itd. Badania nad procesami brzegowymi kształtującymi misy tych zbiorników prowadzili głównie M.A. Rzętała (2003) i M. Rzętała (2008).

W dopływach górnej Wisły i Odry co najmniej od VI w. zakładano stawy, ale racjonalną i nowoczesną gospodarkę rybną rozpropagowali cystersi w XIII w. Gospodarce stawowej sprzyjały dogodne warunki naturalne (zasobne w wodę doliny o umiarkowanym i wyrównanym spadku oraz klimat), a także położenie na skrzyżowaniu głównych szlaków komunikacyjno-handlowych oraz powstawanie nowych dworów i miast (Nyrek 1966). Produkcja pierwotna w stawach naszej strefy klimatycznej jest 3-4 razy większa niż w przypadku upraw polowych (Niedbała 2003), dlatego opłacalne było zalewanie trudnych w uprawie wilgotnych den dolin, a nawet śródpolnych i śródleśnych wądołów. Największy rozwój gospodarki rybnej przypadał na XV-XVI w. (Nyrek 1966, Kocel 1995). Stawy w Kotlinie zajmowały wtedy około 15000 ha, na przełomie XVIII i XIX w. już tylko około 7500 ha (Nyrek 1966). Gospodarka stawowa podupadła na skutek gwałtownego rozwoju górnictwa i przemysłu, które zanieczyszczały rzeki zasilające stawy. Zamulane zbiorniki masowo osuszano i zamieniano na łąki. Część dawnych systemów stawowych funkcjonuje do dziś, stanowiąc, obok nowych, wysoce produkcyjne gospodarstwa. Paciorkowe ułożenie stawów sprawia, że oprócz funkcji gospodarczych i istotnej roli w małej retencji, pełnią one też funkcję zbiorników sedymentacyjnych (Dulias, Pełka-Gościniak 2002). W zachodniej części kotliny pozostałości licznych stawów paciorkowych zachowały się m.in. w okolicach Lysek, Bogunic i Rud (Piech 1998, Czylok i in. 2014). Stawy czynne są jeszcze 
w okolicach Palowic (Śleziak 1997). Przez niedostatek wody przestały funkcjonować także starsze stawy w górnych odcinkach dopływów dolnej Soły. Dla zapewnienia zaopatrzenia w wodę budowano tam szereg młynówek usytuowanych niekiedy piętrowo na zboczach dolin, np. na Górze Grojeckiej. W zlewni Rudy i Suminy zachowały się z kolei pozostałości kanałów ochrony przeciwpowodziowej (Waga 2003, Fajer 2018) w części rozmyte i zamienione przez erozję w przełomy uwarunkowane antropogenicznie (Zygmunt 2002, 2003, Fajer 2018).

Duże zbiorniki usytuowane na prawobrzeżnych dopływach Odry w obrębie Kotliny Raciborsko-Oświęcimskiej pełniły zwykle rolę energetyczną (Kocel 1995, 1997, Fajer i in. 2006), gospodarka hodowlana była w nich realizowana komplementarnie. Po tych zbiornikach zachowały się najczęściej fragmenty grobli piętrzących, a także osady denne w obrębie ich dawnych mis (Klimek, Krąpiec 2003).

Szczególnego rodzaju przeobrażenia rzeźby terenu w Kotlinie Raciborsko-Oświęcimskiej związane są z działaniami militarnymi. Pierwsza grupa form o tym charakterze to różnej wielkości umocnienia, należące do tzw. ars militaris, pochodzące $z$ różnych okresów, np. grodzisko w Lubomi (VIII-IX w.) (Waga, Fajer 2020), system warowny twierdzy Koźle (XVIII-XIX w.), punkty niemieckiej obrony przeciwlotniczej (FlaK) z czasu II wojny światowej, powojenne umocnienia o takim samym przeznaczeniu, strzelnice i transzeje, głównie z II wojny światowej. Druga grupa to pozostałości po eksplozjach ładunków wybuchowych, przede wszystkim bomb. Do obszarów (także w skali Europy) o najbardziej przeobrażonej rzeźbie wskutek tzw. bombardowań powierzchniowych z okresu II wojny światowej należą okolice Kędzierzyna-Koźla i Zdzieszowic w Niecce Kozielskiej (ryc. 6.4).

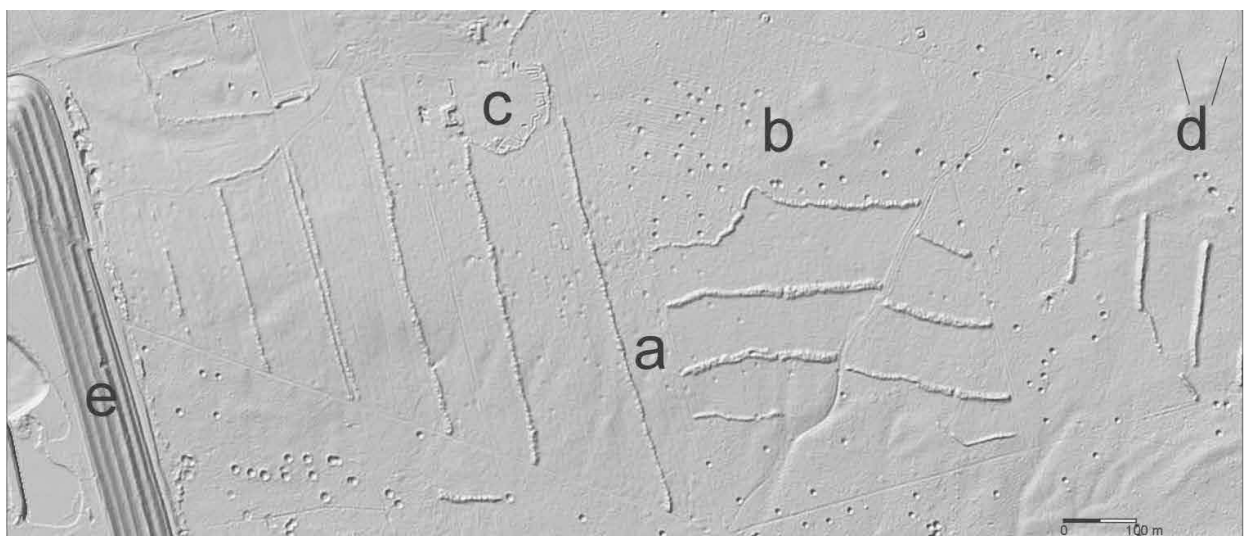

Ryc. 6.4. Antropogeniczne formy terenu koło Kędzierzyna-Koźla (Nadleśnictwo Kędzierzyn obszar na wschód od Zakładów Azotowych Kędzierzyn S.A.) (źródło: polska.e-mapa.net) a - podłużne wały zepchniętych karp korzeniowych i humusu $z$ terenu odsłoniętego pod uprawę sosny, b - leje po bombardowaniach w czasie II wojny światowej zakładu IG Farben w Kędzierzynie, produkującego syntetyczne paliwo lotnicze, c - pozostałości obozu jenieckiego z okresu II wojny światowej, d - pozostałości mielerzy, e - skarpa nadpoziomowego składowiska popiołów z elektrociepłowni Z.A. Kędzierzyn S.A. 
$\mathrm{Na}$ terenach zabudowanych oraz rolnych leje po bombach zostały zasypane, a ich sąsiedztwo wyrównane, jednak na obszarach leśnych i zabagnionych nieużytkach zachowały się liczne nierówności, obserwowane na obrazie LiDAR jako struktury ospowate. Są to głównie kratery eksplozyjne po bombach burzących o średnicy do $15 \mathrm{~m}$ i głębokości do $3 \mathrm{~m}$. W okolicach Kędzierzyna i Zdzieszowic zachowały się pozostałości niemal 5700 dużych lejów i 220 małych (Waga, Fajer 2021b).

W lasach państwowych Górnego Śląska od lat 70. XX w. coraz częściej pojawiają się podłużne zwały warstw humusowych z karpami korzeniowymi (ryc. 6.4). Powstają one w ramach prac urządzeniowych na zrębach. Wraz z degradowaniem naturalnych elementów rzeźby terenu niszczone są ślady dawnej działalności ludzkiej, w tym gospodarki węglarsko-smolarskiej (mielerzy), osad śródleśnych, form należących do ars militaris, a także omawianych tu innych pozostałości działań wojennych.

\subsubsection{Denudacja antropogeniczna i tendencje zmian rzeźby}

Denudacja antropogeniczna na obszarze Kotliny Raciborsko-Oświęcimskiej przez stulecia była związana przede wszystkim z działalnością rolniczą, dopiero w ostatnim stuleciu wzrósł udział denudacji powiązanej z działalnością górniczą. $\mathrm{Na}$ podstawie wydobycia węgla kamiennego i skały płonnej oraz odpowiednich współczynników eksploatacji dla okresu od początku górnictwa (1792) do 2009 r. tempo denudacji obliczono na $11 \mathrm{~mm} \cdot \mathrm{a}^{-1}$. W ostatnich latach (1994-2009) wskaźnik denudacji wynosił średnio $37 \mathrm{~mm} \cdot \mathrm{a}^{-1}$, a w odniesieniu do obszaru bezpośrednich wpływów górniczych dla 9 kopalń przekroczył wartość $100 \mathrm{~mm} \cdot \mathrm{a}^{-1}$ (np. „Jankowice” - $204 \mathrm{~mm} \cdot \mathrm{a}^{-1}$, „Pniówek” - $154 \mathrm{~mm} \cdot \mathrm{a}^{-1}$ ) (Dulias 2011, 2013).

Rozmiary denudacji antropogenicznej obliczone z różnicy cyfrowych modeli wysokościowych dla lat 1883 i 1993 dla Kotliny Raciborsko-Oświęcimskiej jako całości wynoszą $7,5 \mathrm{~mm} \cdot \mathrm{a}^{-1}$, co po uwzględnieniu rozmiarów agradacji rzędu $4,5 \mathrm{~mm} \cdot \mathrm{a}^{-1}$ daje ujemny bilans denudacyjny na poziomie $3 \mathrm{~mm} \cdot \mathrm{a}^{-1}$. Bilans ten jest bardzo zróżnicowany przestrzennie, co widać $\mathrm{w}$ odniesieniu do poszczególnych zlewni, np. dla położonych na Wysoczyźnie Rachowickiej: Ostropki $-2 \mathrm{~mm} \cdot \mathrm{a}^{-1}$, a dla Dopływu z Przyszowic - $53 \mathrm{~mm} \cdot \mathrm{a}^{-1}$.

Obszar Kotliny Raciborsko-Oświęcimskiej jest obecnie głównym rejonem wydobycia węgla kamiennego w Polsce i Europie. Już w 2010 r. z obszaru tego pochodziło 65\% węgla eksploatowanego w Górnośląskim Zagłębiu Węglowym, a $\mathrm{w}$ perspektywie najbliższych 10-30 lat poziom ten zostanie prawdopodobnie utrzymany, gdyż około $2 / 3$ zasobów przemysłowych węgla występuje w podłożu kotliny, a polityka energetyczna Polski na razie jest skierowana na ten surowiec. Mając na uwadze, że największe perspektywy rozwoju górnictwa dają złoża na obszarze Płaskowyżu Rybnickiego i Wysoczyzn Przywyżynnych, odznaczających się degradacyjnym charakterem morfodynamicznym (Bogacki, Starkel 1999), można przyjąć, że współczesne, antropogenicznie uwarunkowane procesy geomorfologiczne będą zachodziły w zbliżonym do obecnego tempie. Można zatem 
prognozować, że w ciągu 30 lat powierzchnia kotliny obniży się średnio o ponad $1 \mathrm{~m}$.

Tempo wypełniania osadami zagłębień bezodpływowych (niecek osiadania i innej genezy) będzie największe na Płaskowyżu Rybnickim, gdyż liczne formy bezodpływowe powstały w wyniku przegrodzenia zwałowiskami, głębokich dolinek o silnie nachylonych zboczach. W agradacji antropogenicznej znaczny udział będzie miała depozycja materiału ze zwałowisk.

Procesy erozji rzecznej będą zachodziły intensywnie, szczególnie na Wysoczyźnie Rachowickiej. Jeżeli tempo erozji rzecznej na niektórych odcinkach koryt będzie porównywalne $z$ dotychczasowym, czyli w przedziale wartości 0,5$24 \mathrm{~cm} \cdot \mathrm{a}^{-1}$, to przy założeniu braku prac hydrotechnicznych teoretycznie można prognozować pogłębienia koryt od $0,15 \mathrm{~m}$ do nawet 7,2 $\mathrm{m}$ w okresie 30 lat.

Górnictwo w opisywanych rejonach kotliny wiąże się z dużym wydobyciem skały płonnej, stąd można oczekiwać dalszego nadsypywania starych zwałów i tworzenia nowych. Przemieszczenia mas skalnych, niejednokrotnie na wielką skalę, będą także związane z rekultywacją zwałowisk oraz z coraz częstszym wykorzystywaniem starego, przepalonego materiału zwałowego $\mathrm{w}$ budownictwie drogowym (Dulias 2016).

\subsection{Kotlina Sandomierska}

\subsubsection{Położenie, granice i podział na jednostki geomorfologiczne}

Kotlina Sandomierska jest największym makroregionem pasa kotlin przedgórskich o powierzchni 14,5 tys. km², położonym na wschód od Bramy Krakowskiej. Ma kształt trójkąta odwadnianego przez Wisłę i jej karpackie dopływy, którego południową podstawą jest próg Pogórza Karpackiego, zachodnim ramieniem krawędź Wyżyny Małopolskiej, wschodnie ramię stanowi Wyżyna Lubelska i krawędź Roztocza (ryc. 6.5). Rozciągłość równoleżnikowa kotliny w granicach Polski sięga $250 \mathrm{~km}$, a południkowa $80-100 \mathrm{~km}$. Jej powierzchnia w obrębie wysoczyzn wznosi się na wysokość od 280 do 210 m n.p.m., zaś koryta rzek leżą na wysokości od 190 m n.p.m. u brzegu Karpat do 138 m n.p.m. poniżej ujścia Sanu do Wisły, w najniższym punkcie Kotliny Sandomierskiej (Starkel 1972). Dna doliny Wisły i Sanu ciągną się wzdłuż obu ramion nizinnego trójkąta i spotykają się na wysokości 142 m n.p.m., między Sandomierzem a Zawichostem. Zbierają one wody większości rzek karpackich, które płynąc zgodnie z ogólnym pochyleniem kotliny na północ, oddzielają kilka centralnie położonych wysoczyzn (płaskowyżów) oraz wysoczyzn przykarpackich. Na podłożu mioceńskim zachowały się resztki osadów lodowcowych z okresu zlodowacenia Sanu (na wschód od doliny Sanu również młodszego zlodowacenia - Buraczyński 2013), z pokrywą piasków przewianych lub lessów. Obejmują one na wschód od doliny Sanu rozległy Płaskowyż Tarnogrodzki (do 230 m n.p.m.), na południe od Przemyśla fragment Płaskowyżu Chyrowskiego. Między Wisłoką, Wisłokiem a Sanem występuje Płaskowyż Kolbuszowski (do $266 \mathrm{~m}$ ), a między Wisłoką i Dunajcem Płaskowyż Tarnowski (do 


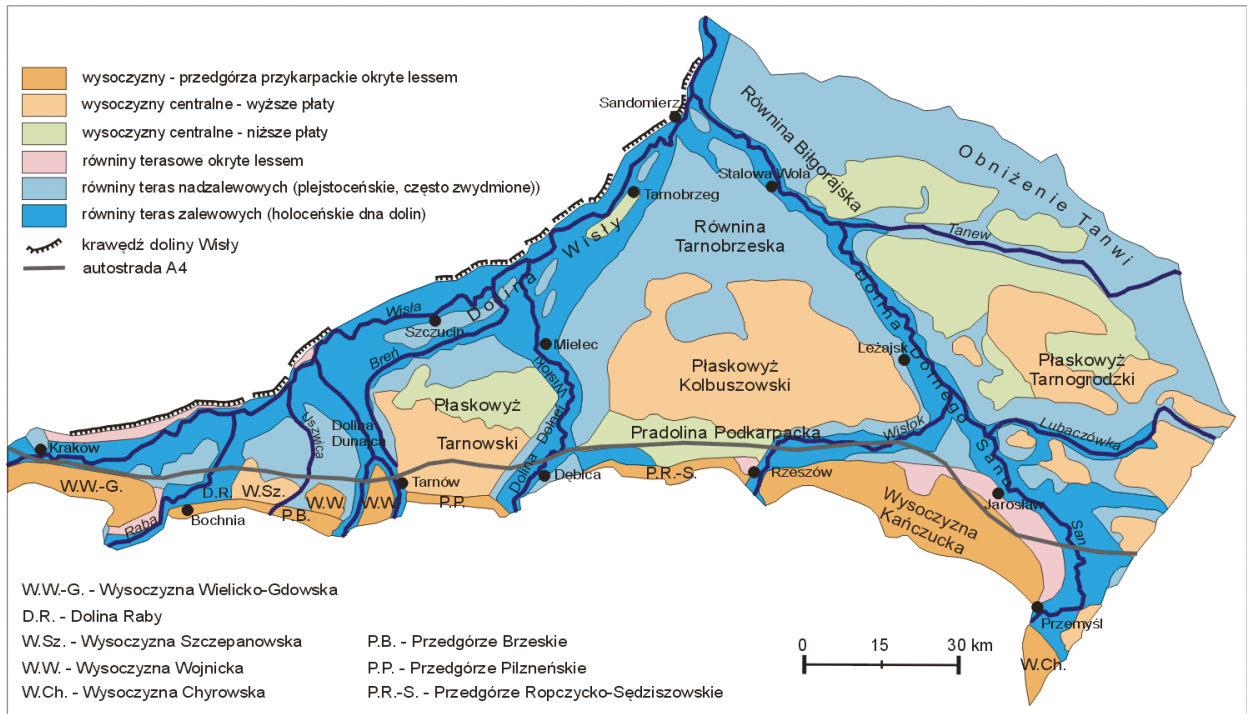

Ryc. 6.5. Jednostki geomorfologiczne i typy rzeźby Kotliny Sandomierskiej (wg Starkla 1972, częściowo zmienione i uzupełnione)

255 m). Na zachód od doliny Dunajca znajdują się mniejsze płaty Wysoczyzny Wojnickiej i Szczepanowskiej (ryc. 6.5). Pomiędzy Płaskowyżem Tarnowskim i Kolbuszowskim a progiem Pogórza i Wysoczyzną Kańczucką ciągnie się równoleżnikowe obniżenie erozyjne zwane Rynną Podkarpacką (Starkel 1972), którym odpływały do dorzecza Dniestru wody roztopowe lądolodu zlodowacenia Sanu. Na odcinku Rzeszów-Przeworsk-Jarosław-Przemyśl rynna wykorzystywana jest przez dna dolin dolnego Wisłoka i Sanu.

\subsubsection{Typy rzeźby i ich budowa geologiczna}

W obrębie Kotliny Sandomierskiej dominują dwa typy rzeźby o różnej wysokości, zespole form i odmiennej budowie geologicznej (Starkel 1972, 2005, Przegladowa mapa geomorfologiczna Polski 1980, Łanczont, Wojtanowicz 2005) (ryc. 6.5). Jeden z nich to wysoczyzny międzydolinne (płaskowyże) o wysokości względnej 40-80 m (210-280 m n.p.m.), rzeźbie pagórkowatej o nachyleniach stoków do $10^{\circ}$ lub płaskiej o nachyleniach nieprzekraczających $5^{\circ}$. Pod utworami czwartorzędowymi zalegają na różnej głębokości iły mioceńskie. Wśród nich można wyróżnić dwa podtypy. Jeden podtyp to gliniasto-piaszczyste wysoczyzny centralne - płaskowyże, przecięte dolinami rzek na kilka płatów (Płaskowyż Szczepanowski, Tarnowski, Kolbuszowski, Tarnogrodzki). Fundament płaskowyżów stanowią mało odporne iły i piaski mioceńskie przykryte żwirami karpackimi, glinami i piaskami lodowcowymi. Na ich powierzchni przeważnie występują wydmy, w części wschodniej okryte są niekiedy lessami (do 10 m miąższości), utworami 
stokowymi lub cienkimi pokrywami pylasto-piaszczystymi genezy eolicznej (okolice Leżajska, Krzeszowa, Lubaczowa i Chotyńca - Wojtanowicz 1997, Gębica, Sokołowski 2001, Gębica i in. 2017). Na Płaskowyżu Kolbuszowskim w rejonie Grodziska występuje zespół kilkudziesięciu małych jeziorek prawdopodobnie genezy termokrasowej (Wojtanowicz, Jóźwiakowska 1997). Drugi podtyp to wysoczyzny przykarpackie - przedgórza położone u stóp progu Pogórza Karpat o wierzchowinach leżących na wysokości 240-280 m n.p.m., szerokości 3-18 $\mathrm{km}$, okryte grubym płaszczem lessu i rozczłonkowane siecią dolin nieckowatych i płaskodennych. Niektóre człony tej listwy (Przedgórze Brzeskie, Pilzneńskie, Ropczycko-Sędziszowskie) zostały włączone do Pogórza Karpackiego (Starkel 1972, 1980), ponieważ leżą na mało odpornych ściętych utworach fliszu lub sfałdowanego miocenu jednostki stebnickiej lub zgłobickiej. Jednak biorąc pod uwagę ich położenie w strefie północnego podnóża Progu, znacznie mniejsze wysokości względne, brak pokrywy leśnej i inne cechy środowiska, zdecydowano, że te wąskie listwy przedgórzy zostają włączone do Kotliny Sandomierskiej (ryc. 6.5). Inne wysoczyzny (Wysoczyzna Kańczucka, Chyrowska, Wojnicka, WielickoGdowska) ścinają mało odporne iły i piaski miocenu zapadliska przedkarpackiego i są przykryte lessem (ryc. 6.5). Są to tereny rolnicze o silnej erozji gleb.

Odmienny zespół form mają szerokie od kilku do kilkunastu kilometrów sterasowane obniżenia dolinne: rozległej doliny Wisły i jej karpackich dopływów (Raby, Dunajca, Wisłoki i Sanu) oraz równoleżnikowego obniżenia Rynny Podkarpackiej - wykorzystywanej przez dolny bieg Wisłoka i Sanu, i obniżenie Tanwi u stóp Roztocza (Starkel 1972, Buraczyński 2013). W ich obrębie zaznaczają się plejstoceńskie równiny teras i stożki piaszczyste o wysokości względnej 8(10)$20 \mathrm{~m}$, często zwydmione, oraz równiny teras z pokrywą lessów (terasa lessowa $\mathrm{u}$ wylotu dolin karpackich i w dolinie Wisły) (ryc. 6.5), rozcięte nieckowatymi dolinkami denudacyjnymi, wąwozami i parowami, a na powierzchni urozmaicone płytkimi zagłębieniami typu wymoków. Plejstoceńskie terasy piaszczyste i centralnie położone płaskowyże pokrywają pola piasków przewianych i wydmy należące do największych w Polsce (Wojtanowicz 1971, 1972, Buraczyński 1991, Izmaiłow 2001, Gębica 2004). Wydmy paraboliczne, wały wydmowe podłużne i poprzeczne o wysokości do $25 \mathrm{~m}$ powstały w późnym vistulianie i na początku holocenu (Wojtanowicz 1971, Izmaiłow 2001, Zieliński i in. 2014, Gębica $\mathrm{i}$ in. 2016). Tworzą one na północnym przedpolu Płaskowyżu Kolbuszowskiego i Równinie Biłgorajskiej zwarte kompleksy wydm.

Zbliżoną rzeźbę mają piaszczyste równiny, występujące na północnym skłonie Płaskowyżu Kolbuszowskiego w widłach Wisły i Sanu (Równina Tarnobrzeska) i południowym stoku Roztocza (Równina Biłgorajska), przykryte eolicznymi piaskami pokrywowymi i zwartymi kompleksami wydm. Piaski tworzące stożki napływowe u wylotu dolin wyżynnych wiązane są z okresem vistuliańskim. U samego progu Roztocza ciągnie się podnóże wysłane deluwiami stokowymi (Buraczyński, Butrym 1989, Łanczont, Wojtanowicz 2005, Buraczyński 2013).

Największe powierzchnie w Kotlinie Sandomierskiej zajmują współczesne równiny zalewowe i nadzalewowe, zbudowane z osadów żwirowo-piaszczystych 
(facji korytowej), przykrytych zmiennej miąższości pokrywą osadów pozakorytowych (mad). Terasę nadzalewową (rędzinna) o szerokości 5-10 km i wysokości 6-8 (10) m rozcinają różnowiekowe generacje holoceńskich paleomeandrów, natomiast terasa zalewowa (łęgowa) o szerokości od $200 \mathrm{~m}$ do $1 \mathrm{~km}$ i wysokości 4-6 m nad poziom koryt była formowana w XVIII-XIX w. przeważnie przez koryta o rozwinięciu roztokowym. Terasa łęgowa jest zalewana w czasie corocznych wezbrań. Terasa rędzinna (nadzalewowa) głównych dolin o wysokości 6-10 m nie jest zalewana w wyniku pogłębienia koryt rzecznych (Starkel 1972, Gębica 2004). Ostatni raz była zalana podczas powodzi w lipcu 1934 r. (Lewakowski 1935). Współczesnym uregulowanym korytom karpackich dopływów Wisły o spadku 0,7-0,3\% i szerokości od 20-50 m do $100-200 \mathrm{~m}$, o krętym przebiegu, towarzyszą lokalnie wąskie listwy przykorytowych teras piaszczystych o wysokości 1-3 m. Po regulacji kilkakrotnemu zmniejszeniu uległy szerokości koryt i na niektórych odcinkach nastąpił wzrost ich spadku, któremu towarzyszyło powszechne pogłębianie koryt (Klimek 1983). Tendencja do pogłębiania koryt trwa.

W samej dolinie Wisły, płynącej Kotliną Oświęcimską, przez Bramę Krakowską i wzdłuż północno-zachodniego obramowania Kotliny Sandomierskiej, na całej długości od Goczałkowic po Zawichost występuje naprzemianległość czterech zasadniczych typów (genetycznych) odcinków dolin: zwężeń (przełomów), rozszerzeń, stref dawnych bifurkacji i odcinków asymetrycznych (Gębica 1995, Starkel 2001). Zwężenia o typie przełomów występują w rejonie Góry (powyżej Brzeszcza), w Bramie Krakowskiej (szerokość doliny w rejonie Tyńca jedynie $400 \mathrm{~m}$ ) i koło Zawichostu. Przeważająca część biegu rzek odznacza się rozszerzeniami dolinnymi, z których największe występują przy połączeniach lejkowatych $z$ dnami dolin dopływów. Powyżej ujść dopływów spotyka się obszary podmokłe $z$ zachowanymi śladami odciętych koryt meandrowych i płaskich (szerokości do $1,5 \mathrm{~km}$ ) zatorfionych obniżeń drenowanych przez małe cieki (np. obniżenie Drwinki w dolinie Wisły, obniżenie Gróbki w dolinie Raby i Kisieliny w dolinie Dunajca). Natomiast poniżej ujścia Dunajca i Wisłoki występują ciągi nieczynnych obecnie obniżeń „zapasowych” szerokości 2-5 km (odwadnianych przez Breń i Trześniówkę), oddzielonych od współczesnego dna doliny płatami zwydmionych teras vistuliańskich lub ostańców erozyjnych (Garb Szczuciński i Tarnobrzeski). Inny typ reprezentują wyraźnie asymetryczne odcinki doliny Wisły (np. między Nowym Brzeskiem a Opatowcem), w których koryto Wisły spychane przez karpackie dopływy - Rabę i Dunajec - pod krawędź Wyżyny Małopolskiej, podcina ją, co spowodowało odcięcie od lewobrzeżnej terasy lessowej pagórów meandrowych (Trawniki i Skała w rejonie Grobli - Gębica 1995) czy wzgórza Pączek koło Sandomierza, leżących obecnie na prawym brzegu doliny (ryc. 6.5).

Wisła płynie korytem w przewadze meandrowym o średnim spadku 0,25\%o, szerokości od 80 do $300 \mathrm{~m}$, ograniczonym wałami z towarzyszącymi mu wąskimi listwami terasy łęgowej i wysokiej na 4-6 m terasy rędzinnej (nadzalewowej), szerokości do $10 \mathrm{~km}$. Terasa nadzalewowa rozcięta jest systemami różnowiekowych starorzeczy holoceńskich, coraz młodszych w kierunku współczesnego koryta, co świadczy o stałym przesuwaniu się koryta Wisły w kierunku północnym. 
Do terasy rędzinnej doliny Wisły dowiązują wyloty mniejszych dolin drenujących obszar Kotliny Sandomierskiej (Breń, Trześniówka, Mokrzyszówka, Łęg i inne), które w odróżnieniu od górskich rzek odprowadzają powoli wody opadowe. Wysoczyzny charakteryzują się ograniczoną retencją i powolnym spływem wód, natomiast główne doliny rzek wypełnione miąższymi aluwiami cechuje przemieszczanie się fal powodziowych i najbogatsze zbiorniki wód podziemnych (Starkel 1998).

\subsubsection{Współczesne procesy geomorfologiczne - uwarunkowania i skutki}

Natężenie oraz przebieg współczesnych procesów rzeźbotwórczych uwarunkowane jest cechami środowiska naturalnego i działalnością człowieka.

\subsubsection{Procesy stokowe}

Informacje na temat współczesnych procesów denudacyjnych na terenie Kotliny Sandomierskiej są bardzo skromne. Dlatego oceniając intensywność i skutki współczesnych procesów morfogenetycznych, możemy posłużyć się wynikami badań ze Stacji Terenowej Uniwersytetu Jagiellońskiego w Łazach, położonej na pograniczu Pogórza Wiśnickiego i Przedgórza Brzeskiego. Na wysoczyznach zbudowanych z pokryw piaszczysto-gliniastych, o na ogół przepuszczalnych glebach i łagodnie nachylonych stokach, spłukiwanie nie odgrywa większej roli, chociaż efekty rozbryzgu w postaci ubijania (rozmywania) gleby na polach ornych przez bombardującą działalność kropel deszczu, były obserwowane na Płaskowyżu Tarnowskim w czerwcu 2009 r. (Gębica i in. 2019). Jest ono natomiast intensywne w pasie Przedgórza Brzeskiego na glebach powstałych na podłożu lessowym, gdzie w czasie dwóch największych ulew w 2007 r. ekstremalne spłukiwanie (zmyw) gleby na poletkach pomiarowych Stacji w Łazach wynosiło odpowiednio 13,6 t $\cdot \mathrm{ha}^{-1}$ i 19,43 t $\cdot h a^{-1}$ (Święchowicz 2010). Natomiast wartość natężenia spłukiwania $43,4 \mathrm{t} \cdot \mathrm{ha}^{-1} \cdot \mathrm{a}^{-1}$ dla okresu obserwacyjnego $2007-2008$ na Stacji w Łazach jest znacznie niższa niż dla sąsiednich obszarów pogórskich (Święchowicz 2010). Erozja linijna i spłukiwanie gleby ma miejsce na stokach w czasie roztopów i nawalnych opadów, zwłaszcza na wiosnę na polach z uprawami okopowymi. $\mathrm{Na}$ Przedgórzu Ropczycko-Sędziszowskim w czasie opadów rozlewnych 3 czerwca 2006 r. z maksymalnym opadem 10,3 mm (w czasie 1 godziny) w dniu 4 czerwca na łagodnie nachylonym stoku $z$ uprawami buraków powstały bruzdy i żłobiny erozyjne o długości 20-100 m i głębokości kilkudziesięciu centymetrów. U podnóża stoku zostały zdeponowane pokrywy deluwialne o miąższości od kilku do kilkunastu centymetrów (Długosz, Gębica 2008, Gębica i in. 2019) (ryc. 6.6). Podczas krótkotrwałych ulew gęsta sieć dróg koncentruje zwykle znaczną część spływu powierzchniowego. Na drogach polnych powstają żłobiny erozyjne, a także małe kociołki eworsyjne. Na przykład w czasie ulewy 20 sierpnia $2004 \mathrm{r}$. w rejonie Pilzna (maksymalny opad dobowy $72 \mathrm{~mm}$ ) u wylotu dróg zostały zakumulowane płaskie stożki zbudowane $z$ materiału żwirowego i błota. Zniszczeniu uległy nawierzchnie asfaltowe dróg, obejmujące niekiedy $30 \%$ ich powierzchni 


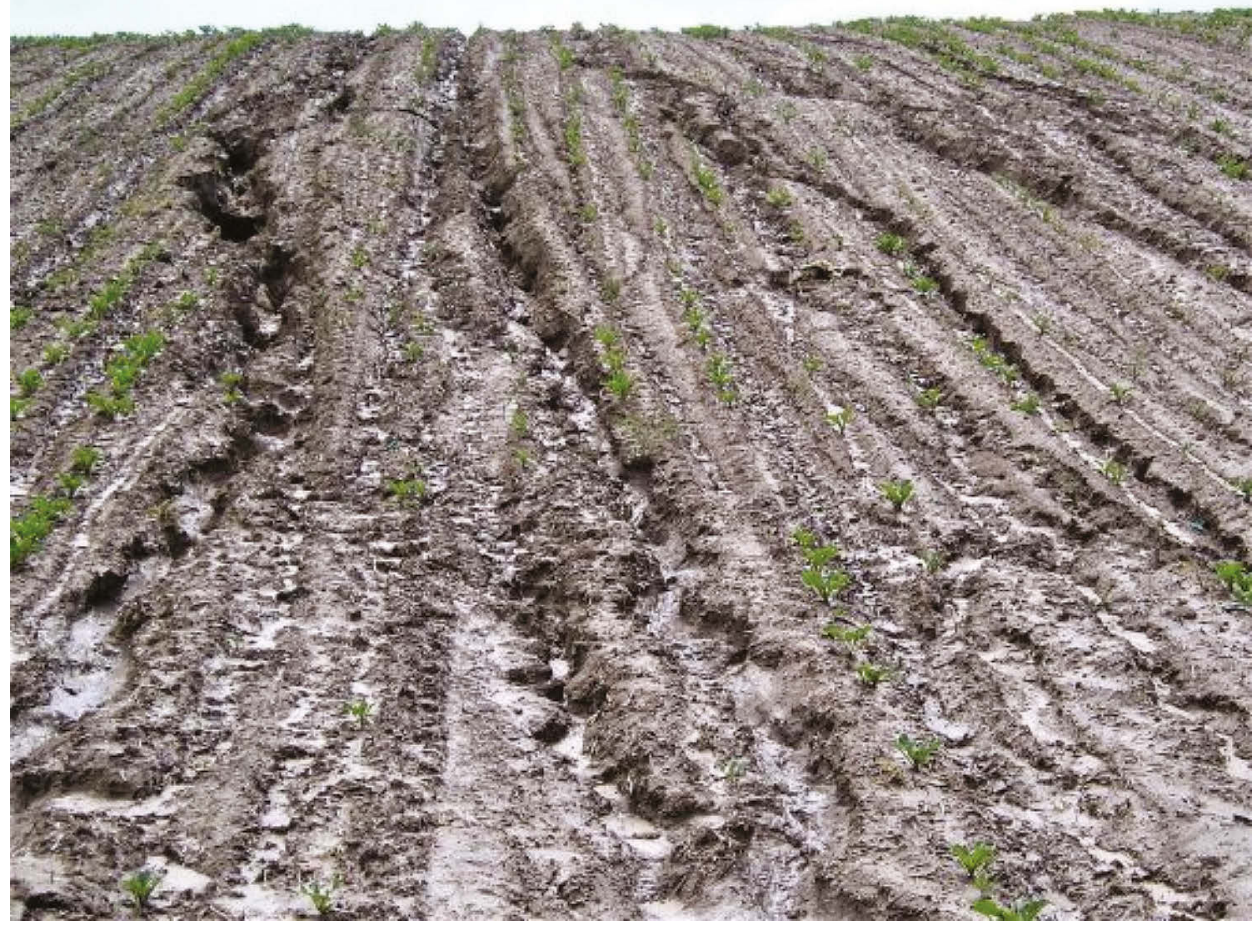

Ryc. 6.6. Efekty spłukiwania na stoku z uprawami po ulewie w czerwcu 2006 r. w Sędziszowie Małopolskim (Przedgórze Ropczycko-Sędziszowskie) (fot. P. Gębica)

(Gębica i in. 2019). Znacznie bardziej spektakularne efekty intensywnej erozji gleb obserwowano w maju 2010 r. na Przedgórzu Brzeskim koło miejscowości Jasień Brzeski na północ od drogi krajowej E40, gdzie na polu kukurydzy powstały żłobiny (bruzdy) erozyjne i rozdoły o długości kilkudziesięciu metrów, szerokości $5 \mathrm{~m}$ i głębokości prawie $3 \mathrm{~m}$ (Kijowska 2011). Spowodowała je gwałtowna ulewa w dniu 16 maja 2010 r. o łącznej sumie opadu 91,9 mm i natężeniu deszczu 0,26 mm na minutę zanotowana na Stacji Terenowej Uniwersytetu Jagiellońskiego w Łazach koło Brzeska (Kijowska 2011), tj. około $5 \mathrm{~km}$ od obszaru badań. Pogłębianie żłobin i wcięć drogowych (głębocznic) podczas ulew prowadzi do powstania wąwozów (Wysoczyzna Kańczucka, Płaskowyż Kolbuszowski).

Procesem groźnym w skutkach jest osuwanie. Chociaż osuwiska na terenie Kotliny występują nielicznie (punktowo) w porównaniu z progiem Pogórza Karpat, to w niektórych miejscach ich udział jest większy. Do takich miejsc należą podcinane zbocza dolin, np. w dolinie Wisły poniżej Nowego Brzeska (Gębica 1995), Sandomierza czy doliny Sanu koło Krzeszowa (Płaskowyż Tarnogrodzki). O podcinaniu przez Wisłę południowej stromej krawędzi Wyżyny Małopolskiej świadczą liczne dane historyczne (Starkel 1967). Osuwiska stokowe rozwijają się zazwyczaj na obszarach zbudowanych z nieprzepuszczalnych iłów mioceńskich 
z pokrywą lessów, jak to ma miejsce na obszarze Wysoczyzny Kańczuckiej koło Łańcuta i na Przedgórzu Brzeskim. Przeważają osuwiska nieczynne, ale wiele $z$ nich uaktywnia się $w$ latach wilgotnych.

\subsubsection{Procesy fluwialne}

Procesy fluwialne obejmujące erozję, transport i akumulację zachodzą stale, ze zmiennym natężeniem, w korytach rzecznych i okresowo w czasie wezbrań na równinie zalewowej. O przebiegu i natężeniu procesów fluwialnych decyduje reżim hydrologiczny zdeterminowany warunkami klimatycznymi (szczególnie opadami) i cechy fizjograficzne zlewni. Obszar Kotliny Sandomierskiej narażony jest zarówno na krótkotrwałe ulewy i deszcze nawalne, jak i długotrwałe opady rozlewne (Chomicz 1951, Starkel 1996, Cebulak, Niedźwiedź 1998), powodujące wezbrania na rzekach dużych i mniejszych. Wahania stanów wody są rzędu 7-9 m, w dolinie dolnego Dunajca mogą osiągać nawet 10,5 m (Punzet 1983). Skala wahań stanów wody wskazuje, że gdyby nie było obwałowań, zalaniu uległyby równiny zalewowe $z$ niższymi fragmentami terasy vistuliańskiej. Zdarza się to $\mathrm{w}$ czasie katastrofalnych powodzi, kiedy przerwaniu ulegają wały powodziowe. Krótkotrwałe ulewy, trwające najczęściej od 0,5 do 3 godzin o wysokości opadu 50-150 mm, zazwyczaj połączone są z burzami i charakteryzują się dużymi natężeniami, przekraczającymi $20 \mathrm{~mm}$ w ciągu 10 minut. Ulewy na obszarach równinnych Kotliny Sandomierskiej prowadzą do wypełnienia rowów wodą opadową, podniesienia poziomu wód gruntowych i stagnacji wody w obniżeniach przez wiele dni, np. po ulewach w czerwcu 2009 r. i w maju 2019 r. (ryc. 6.7, typ II) (Starkel 1967, 2011, Gębica i in. 2019) (ryc. 6.8). Opady rozlewne trwające przez 1-3 dni, osiągają do $100-250 \mathrm{~mm}$ i wiążą się zwykle z przechodzeniem frontów atmosferycznych, obejmujących większe obszary zlewni. Okresowe wzrosty natężeń sprzyjają kształtowaniu się fal wezbraniowych, które u zbiegu rzek nakładają się na siebie. W Kotlinie Sandomierskiej fale powodziowe rzek karpackich na ogół nakładają się na wcześniej uformowane wezbranie na górnej Wiśle, wspomaganej przez Dunajec, Rabę i inne dopływy górskie. W dnach dolin o obwałowanych korytach szczególnie groźna sytuacja powstaje, gdy nakładają się równocześnie dwie fale powodziowe, np. Wisły i Wisłoki lub Wisły i Dunajca, i przy przesiąknięciu wałów dochodzi do ich przerwania (np. w 1997, 2001 i 2010 r.) (ryc. 6.7, typ I) (ryc. 6.9). Powstają wówczas kotły eworsyjne (krewasy). Największa $z$ nich utworzona w Komorowie na lewym brzegu Wisły miała 300 m długości, 200 m szerokości, a jej głębokość sięgała 10,5 m. Wokół krewas miejscami tworzyły się bruzdy erozyjne o długości kilkunastu metrów i głębokości kilkudziesięciu centymetrów. Miejscami występowała strefa transportu materiału z rozwiniętą cienką pokrywą bruku korytowego. Na zewnątrz od krewas utworzyły się stożki (glify) krewasowe, zbudowane z piasków i żwirów o miąższości do $1 \mathrm{~m}$. W osadach powszechne było występowanie toczeńców mułowych o maksymalnej średnicy 1,3 m oraz pni czarnych dębów redeponowanych ze starszych aluwiów (Gębica, Sokołowski 1999) (ryc. 6.10). Niekiedy wezbrania są synchroniczne. Wówczas małe dopływy (Breń, Łęg) gromadzą wodę w zawalu 
Ryc. 6.7. Przebieg różnych typów powodzi w Kotlinie Sandomierskiej (wg Starkla 1967, częściowo zmienione)

I - wezbranie spowodowane napływem wód $z$ Karpat (deszcze rozlewne w górach), przerwanie wałów powodziowych dużych rzek i zalanie równiny zalewowej (np. w 1960, 1997)

II - wezbranie spowodowane równoczesnymi opadami ulewnymi w Karpatach i w Kotlinie Sandomierskiej, wezbranie w strefie międzywala dużej rzeki, zalanie równiny za wałami przez wody małych cieków spływających $\mathrm{z}$ terenu kotliny (np. 1998, 2009, 2019)

III - powódź katastrofalna spowodowana równoczesnymi opadami ulewnymi w Karpatach i w Kotlinie Sandomierskiej $\mathrm{z}$ dwoma lub trzema falami wezbrań na dużej rzece i przerwaniem wałów, podparcie wód wezbraniowych małych cieków spływających z kotliny (np. 2010)

1 - aluwia w dnach dolin, 2 - podłoże (miocen), 3 spływ wód gruntowych do koryta, 4 - infiltracja wód w aluwia, 5 - przesiąkanie wód $\mathrm{z}$ powierzchni równiny zalewowej, 6 - przesiąkanie wód pod wałami (przebicie hydrauliczne), 7 - opadanie i wzrost fali wezbraniowej: $\mathrm{a}$ - opadanie fali, b - wzrost fali powodziowej, 8 - napływ wód wezbraniowych dużej rzeki i podparcie wód wezbraniowych małych cieków spływających z kotliny, 9 - wały przeciwpowodziowe, 10 - budynki mieszkalne i gospodarcze

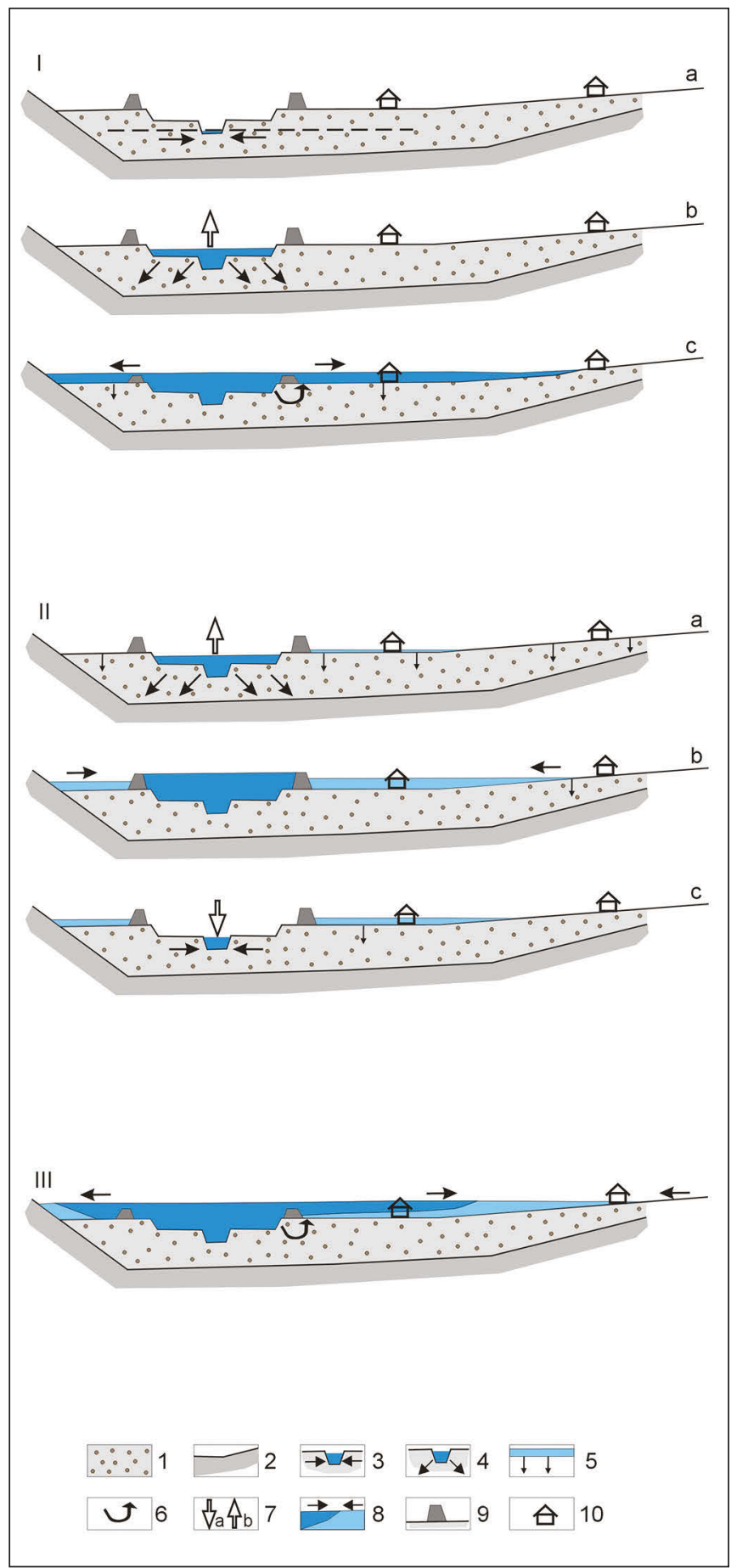




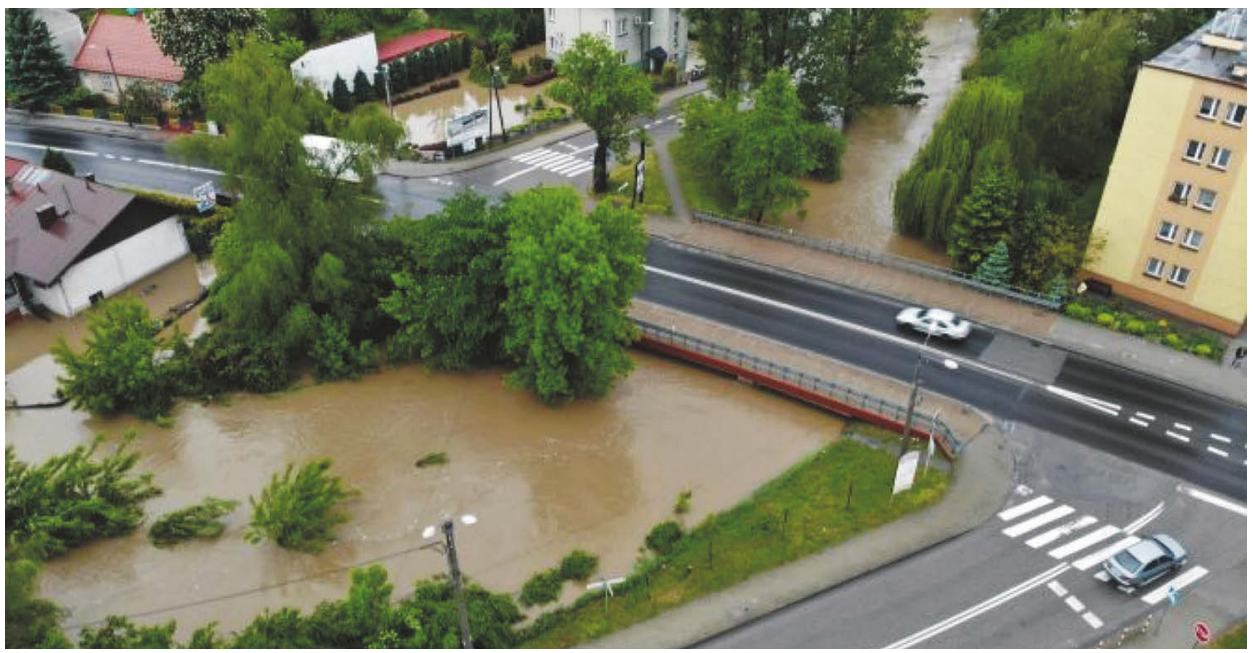

Ryc. 6.8. Mały potok Breń spływający z Wysoczyzny Tarnowskiej zalewa Dąbrowę Tarnowską w maju 2019 r. (fot. Archiwum Powiatowego Centrum Zarządzania Kryzysowego w Dąbrowie Tarnowskiej)

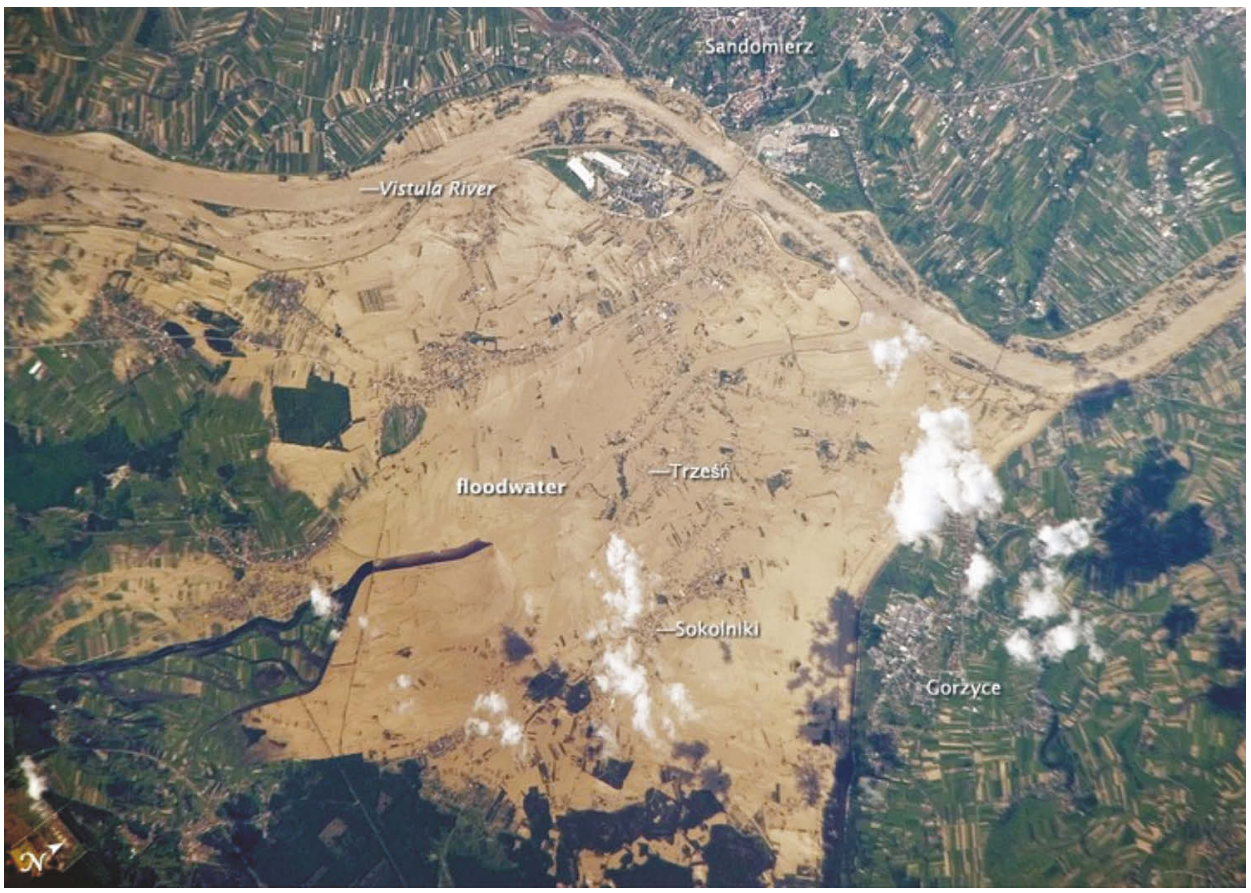

Ryc. 6.9. Zasięg wód powodziowych w widłach Wisły i Łęgu w północnej części Kotliny Sandomierskiej w maju 2010 r. (na podstawie zdjęcia satelitarnego udostępnionego na serwerze Forsal.pl; dostęp: 14.05.2014) 
Wisły, a ich odpływ blokuje nadchodząca fala na Wiśle. Takie zjawisko miało miejsce podczas powodzi w czerwcu 2010 r. (por. ryc. 6.7, typ III) (Gębica i in. 2019).

Koryta karpackich dopływów Wisły w południowej części Kotliny (u brzegu gór) zostały pogłębione o 2-3 m w XX w. (Punzet 1981, Klimek 1991) i docięły się do grubofrakcyjnych żwirów (bruków), dlatego terasa rędzinna (nadzalewowa) o wysokości 7-10 m nie jest obecnie zalewana. Proces pogłębiania koryt trwa. Przyczyną tego zjawiska jest przede wszystkim regulacja koryt i eksploatacja żwirów z koryta na skalę przemysłową, szczególnie w latach 50. i 60. ubiegłego stulecia, co miało miejsce np. w dolinie Wisłoki.

W północnej części Kotliny Sandomierskiej nie obserwuje się tak wyraźnego pogłębiania koryt rzecznych. W dolinach małych rzek, dopływów Wisły spływających z wysoczyzn (Breń, Łęg) przeważa akumulacja drobnoziarnistej zawiesiny i nadbudowywanie den dolin, chociaż przypadki przerywania wałów powodziowych, krewasowania naturalnych wałów wydmowych i powstawania glifów

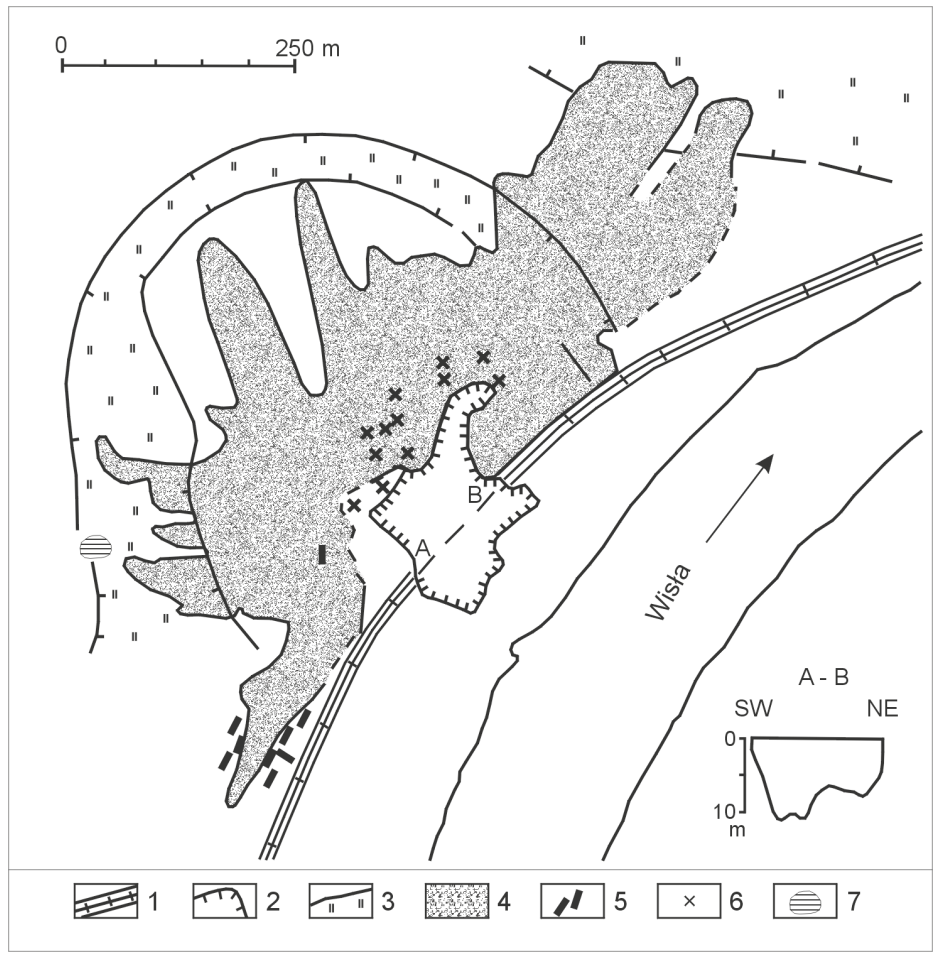

Ryc. 6.10. Przykład kotła eworsyjnego i stożka krewasowego powstałego wskutek przerwania wału powodziowego Wisły w 1997 r. w rejonie Komorowa (wg Gębicy, Sokołowskiego 1999, zmienione)

1 - wały przeciwpowodziowe, 2 - rynna eworsyjna, 3 - starorzecze, 4 - stożek (glif) krewasowy, 5 - pnie drzew (czarne dęby), 6 - głazy i toczeńce mułowe, 7 - stawy 


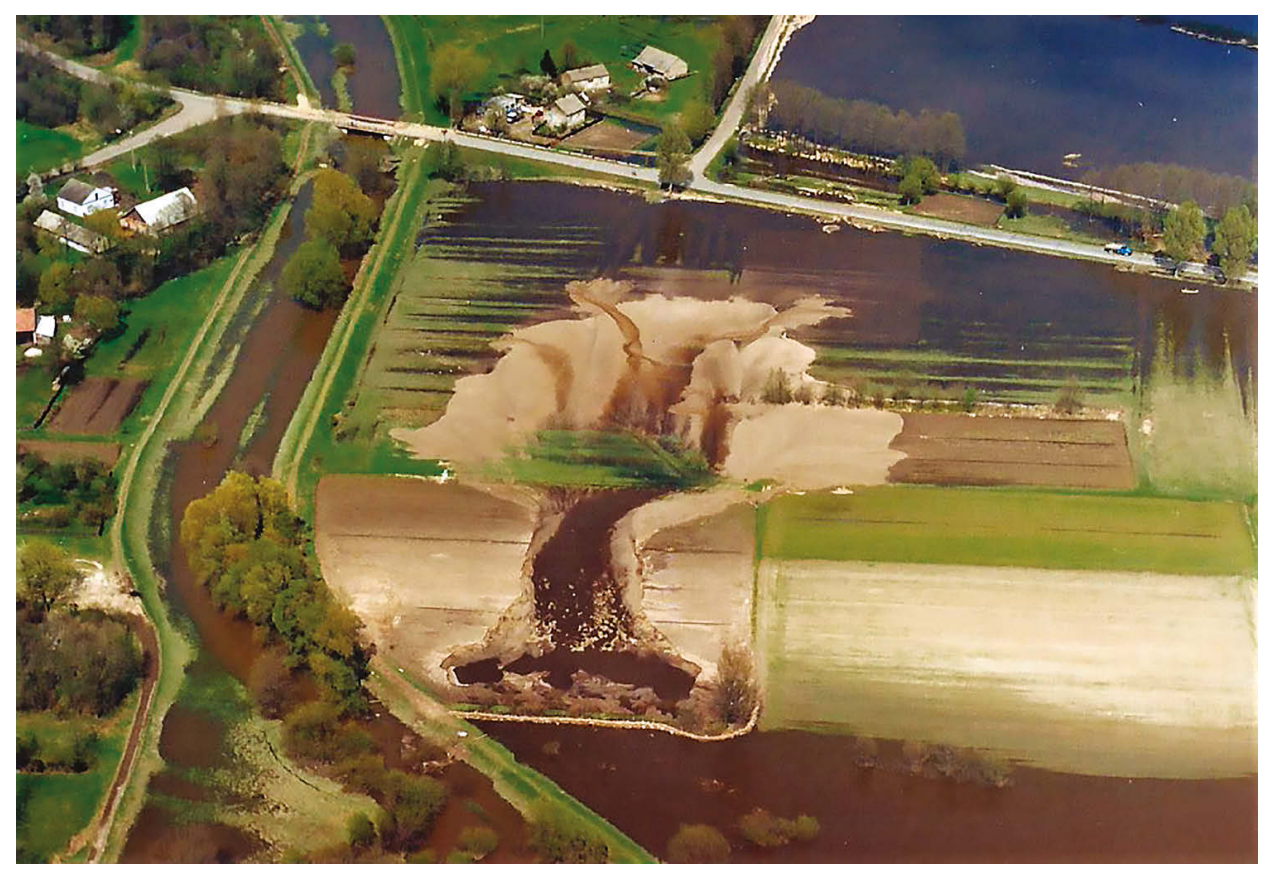

Ryc. 6.11. Lokalna powódź w dolinie potoku Breń na południe od Szczucina w kwietniu 1998 r. Wody powodziowe rozcięły wydmę, tworząc rynnę eworsyjną i glif (stożek) krewasowy, co spowodowało zalanie miejscowości Małec i Suchy Grunt (fot. P. Gębica)

krewasowych były również obserwowane (Gębica, Sokołowski 2002, Gębica i in. 2019) (ryc. 6.11).

\subsubsection{Procesy eoliczne}

Niewiele wiemy na temat współczesnych procesów eolicznych w Kotlinie Sandomierskiej. Rozwiewanie wydm i uaktywnienie procesów eolicznych w czasach nowożytnych w północnej części Kotliny można prawdopodobnie łączyć z wycinką lasów na potrzeby rozwijającego się osadnictwa i lokalnego przemysłu w XVIII i XIX w. (Równina Rozwadowska i Biłgorajska) (Florek 2005). Przemieszczanie się piasków wydmowych ma również miejsce obecnie, gdzie została usunięta pokrywa roślinna. W okresach zimowych $\mathrm{w}$ czasie silnych wiatrów wiejących z południa na obszarach uprawnych lessowego Przedgórza Ropczycko-Sędziszowskiego dochodzi miejscami do przewiewania materiału glebowego ze śniegiem.

\subsubsection{Procesy i formy antropogeniczne}

Eksploatacja złóż siarki w północnej części Kotliny Sandomierskiej w rejonie Tarnobrzega, początkowo metodą odkrywkową, a następnie podziemnego wytopu, spowodowała powstanie zwałowisk skały płonnej i wyrobisk eksploatacyjnych. 
Od kilkunastu lat zaprzestano eksploatacji siarki i na miejscu wyrobiska górniczego w 2009 r. powstał w Machowie (obecnie część Tarnobrzega) wielki sztuczny zbiornik (tzw. Jezioro Tarnobrzeskie) wypełniony wodą z Wisły, użytkowany głównie dla celów rekreacyjnych. Jego powierzchnia wynosi $4,55 \mathrm{~km}^{2}$ i głębokość $42 \mathrm{~m}$.

Znaczącym elementem krajobrazowym i antropogenicznym kotliny jest autostrada A4, której poszczególne odcinki były budowane w latach 2007-2016. Autostrada A4 biegnie w południowej części Kotliny Sandomierskiej od granicy Polski z Ukrainą (przejście graniczne w Korczowej) do Krakowa, na północ od drogi krajowej nr 4 (dawna droga E22) (ryc. 6.5). Trasa autostrady przecina zróżnicowane typy rzeźby i jednostki geomorfologiczne omówione w podrozdziale 6.2.2. Odcinek wschodni autostrady o długości 161,5 km (od węzła Korczowa do Tarnowa) na terenie województwa podkarpackiego i częściowo małopolskiego przecina południowy fragment Płaskowyżu Tarnogrodzkiego, dolinę Wiszni i Sanu na południe od Radymna. Na odcinku od Radymna do Przeworska autostrada biegnie z SE na NW na Wysoczyźnie Kańczuckiej, a następnie wykorzystuje 70-kilometrowej długości równoleżnikowy odcinek Rynny Podkarpackiej (między Przeworskiem a Dębica). Odcinek zachodni o długości 83,5 km (od węzła Krzyż na północ od Tarnowa do Krakowa) położony jest na terenie województwa małopolskiego. Trasa tego odcinka autostrady przecina Wysoczyznę Tarnowską, dolinę Dunajca (Równina Radłowska) i Przedgórze Brzeskie oraz dolinę Uszwicy na NE od Brzeska. Dalej na zachód biegnie południowym skrajem stożka Raby i północnym skłonem Wysoczyzny Wielicko-Gdowskiej oraz doliną Wisły (odcinek Szarów-Niepołomice-Wieliczka-Kraków). W latach 2018-2020 planowana jest również budowa nowego węzła autostrady w rejonie Niepołomic.

Powierzchnia terenów utwardzonych zajętych przez pas autostrady o szerokości 30 m w obu kierunkach między węzłami Korczowa i Krzyż koło Tarnowa na odcinku 161,5 km wynosi 4,845 $\mathrm{km}^{2}$. Wliczając do tego drogi serwisowe, które biegną równolegle do autostrady i stanowią $80 \%$ długości całej autostrady, należy stwierdzić, że łączna powierzchnia zajęta przez utwardzony pas autostrady A4 na odcinku Korczowa-Krzyż wynosi 5,97 km² (ryc. 6.12). Natomiast objętość materiału skalnego budującego nasypy autostrady między węzłami Korczowa i Krzyż (przyjmując szerokość nasypu w górnej części 50 m, a szerokość podstawy nasypu $60 \mathrm{~m}$ i jego wysokość $4 \mathrm{~m}$ ), wynosi około 35,5 $\mathrm{mln} \mathrm{m}^{3}$. Równocześnie wzrosła gęstość dróg niższego rzędu, a także doprowadzenia dróg dojazdowych do gospodarstw na terenach, gdzie osadnictwo jest rozproszone, np. w dolinie Brenia, którego dno jest często obejmowane przez lokalne powodzie, np. w 2009 i $2019 \mathrm{r}$.

Budowa autostrady A4 i dróg szybkiego ruchu spowodowała wzrost zapotrzebowania na miejscowe kruszywo naturalne (piaski i żwiry) wykorzystywane do budowy dróg. Dlatego na terenach wzdłuż autostrady powstało wiele nowych piaskowni i żwirowni, z których część jest obecnie już nieczynna. W dolinie Wisłoka między Łukawcem a Gniewczyną Tryniecką znajduje się kilkanaście czynnych piaskowni i żwirowni o powierzchni wyrobisk od 0,5 do $2-3$ ha. 


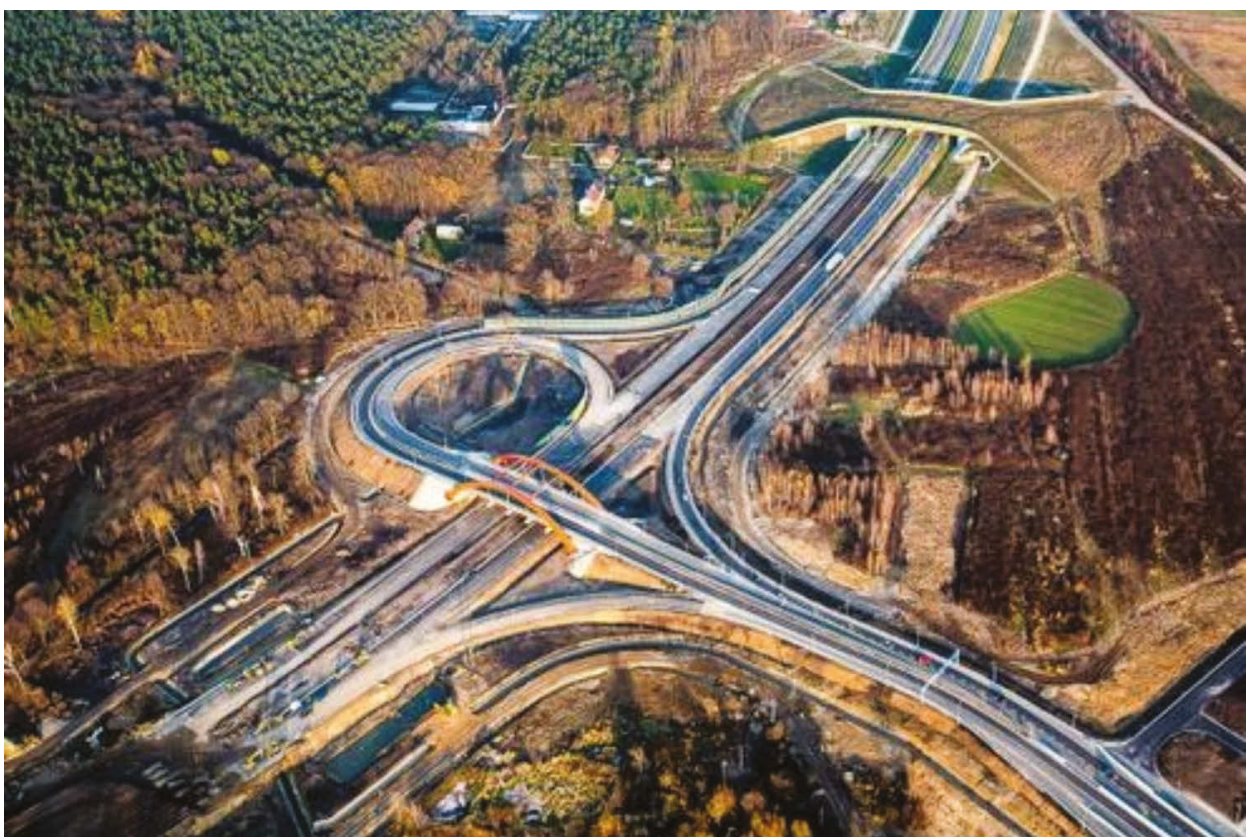

Ryc. 6.12. Autostrada A4 - węzeł w rejonie Jarosławia na wschód od Rzeszowa. Nasypy drogowe i utwardzone odcinki dróg zajmować będą coraz większe powierzchnie terenu (fot. GDDKiA, https://www.rzeszow-news.pl/wp-content/uploads/2014)

\subsubsection{Przewidywane tendencje przekształceń rzeźby kotliny - wpływ czynników naturalnych} i antropogenicznych

Ekstremalne procesy fluwialne (pozakorytowe) w Kotlinach Podkarpackich w warunkach antropopresji (wymuszone zabudową hydrotechniczną koryt) będą się nasilać. Powstawanie kotłów eworsyjnych i stożków krewasowych należy uznać za najważniejszy i najbardziej spektakularny proces rzeźbotwórczy w przypadku rzek o korytach uregulowanych i sztucznie obwałowanych. W czasie kolejnych powodzi i w przypadku nie najlepiej utrzymywanych przez odpowiednie służby wałów przeciwpowodziowych procesy te będą częstsze i zarazem staną się dominującymi procesami geomorfologicznymi w dolinach rzek objętych sztuczną zabudową hydrotechniczną.

\subsubsection{Podsumowanie i wnioski}

Podsumowując, należy stwierdzić, że stan rozpoznania współczesnych procesów rzeźbotwórczych w Kotlinie Sandomierskiej, z wyjątkiem procesów fluwialnych, jest słaby. Kotlina Sandomierska w porównaniu z sąsiednimi regionami geomorfologicznymi to generalnie strefa o przewadze agradacji. Spełnia ona rolę zbiornika sedymentacyjnego gromadzącego osady rzek płynących zarówno z Karpat, jak 
i po wezbraniach mniejszych rzek mających źródła w kotlinie. Natężenie procesów degradacyjnych jest słabe.

\section{Podziękowania}

Składamy serdeczne podziękowania Mariuszowi Montusiewiczowi z Generalnej Dyrekcji Dróg Krajowych i Autostrad w Rzeszowie za informacje udzielone na temat powierzchni utwardzonej zajętej przez pas autostrady A4, a także obliczeń objętości materiału budującego nasypy autostrady między Korczową a Tarnowem.

\section{Literatura}

Bogacki M., Starkel L., 1999, Typologia i regionalizacja wspótczesnych procesów rzeźbotwórczych, [w:] L. Starkel (red.), Geografia Polski. Środowisko przyrodnicze, Wyd. Naukowe PWN, Warszawa, s. 396-427.

Buraczyński J., 1991, Rzeźba eoliczna. Kotlina Sandomierska-Roztocze, skala 1:100 000, Inst. Nauk o Ziemi UMCS, Lublin.

Buraczyński J., 2013, Rozwój rzeźby Roztocza z mapa geomorfologiczna w skali 1: 50 000, Lublin, s. 1-111.

Buraczyński J., Butrym J., 1989, The Vistulian development of a sandy plain in the Sandomierz Basin, Quaest. Geogr., Spec. Issue, 2, 17-30.

Cebulak E., Niedźwiedź T., 1998, Ekstremalne zjawiska opadowe $w$ dorzeczu górnej Wisty $w$ latach 1995-1996, [w:] L. Starkel (red.), Geomorfologiczny i sedymentologiczny zapis lokalnych ulew, Dokumentacja Geogr., 11, 11-30.

Chmielowska I., 1995, Wptyw eksploatacji KWK „1 Maja” na zmiany w środowisku geograficznym na obszarze pola górniczego, Uniwersytet Śląski, WNoZ, Sosnowiec (praca magisterska).

Chomicz K., 1951, Ulewy i deszcze nawalne w Polsce, Wiadomości Służby Hydrologicznej i Meteorologicznej, 2, 3, 5-88.

Ciszewski D., Czajka A., 2009, Akumulacja osadów na równinach zalewowych rzek silnie zmienionych antropogenicznie: górna Wisła i Odra, Przegląd Geologiczny, 57, 7, 576-583.

Czaja S., 1988, Zmiany działu wodnego Wisła-Odra w obrębie Górnośląskiego Okręgu Przemysłowego, Geographia, Studia et Dissertationes, 11, 95-100.

Czajka A., 2007, Środowisko sedymentacji osadów przykorytowych rzek uregulowanych na przykładzie górnej Odry i górnej Wisty, Wyd. Uniwersytetu Śląskiego, Katowice.

Czylok A., Fajer M., Waga J.M., Blaut-Howaniec K., 2014, Waloryzacja przyrodnicza gminy Lyski, Etap 1, Materiały wejściowe do rozdziałów dotyczacych przyrody ożywionej: Metodyka prac inwentaryzacyjnych, Materiaty wejściowe do rozdziatów dotyczacych przyrody nieożywionej, Cel $i$ metody pracy, Charakterystyka budowy geologicznej, rzeźby terenu, pokrywy glebowej, wód, zagadnienia klimatyczne, Urząd Gminy Lyski (maszynopis).

Długosz M., Gębica P., 2008, Geomorfologiczne skutki oraz rola lokalnych ulew $i$ powodzi w kształtowaniu rzeźby progu Pogórza Karpackiego (na przykładzie ulewy z czerwca $r$. $w$ rejonie Sędziszowa Małopolskiego), Landform Analysis, 8, 13-20.

Dulias R., 2002, Procesy eoliczne w strefie maksymalnego zasięgu zlodowacenia środkowopolskiego na Wysoczyźnie Golejowskiej, Geographia, Studia et Dissertationes, 25, 18-32.

Dulias R., 2008a, Wptyw górnictwa węglowego na zmiany krajobrazu w zlewniach Dębinki i Pniówka na Płaskowyżu Rybnickim, Dokumentacja Geograficzna IGiPZ PAN, 37, 144-149. 
Dulias R., 2008b, Mining subsidence in Oświęcim Basin (Carpathian Foredeep), Geomorphologia Slovaca et Bohemica, 8, 2, 7-13.

Dulias R., 2009, Obróbka osadów czwartorzędowych w Kotlinie Oświęcimskiej, [w:] R. Dulias, J. Pełka-Gościniak, O. Rahmonov (red.), Ekosystemy piaszczyste i człowiek, Prace Wydziału Nauk o Ziemi Uniwersytetu Śląskiego, 58, 77-83.

Dulias R., 2011, Impact of mining subsidence on the relief of the Rybnik Plateau, Poland, Zeitschrift für Geomorphologie, 55, 25-36.

Dulias R., 2013, Denudacja antropogeniczna na obszarach górniczych na przykładzie Górnoślaskiego Zagłębia Węglowego, Uniwersytet Śląski, Katowice.

Dulias R., 2016, The impact of mining on the landscape. A study of the Upper Silesian Coal in Poland, Springer Int. Publ., Switzerland.

Dulias R., Pełka-Gościniak J., 2002, The importance of ponds in the landscape of PielgrzymowiceOświęcim Basin, [w:] V.N. Andrejchuk, V.P. Korzhyk (red.), Regional aspects of land use, Technical University in Chernivtsy, Department of Ecology and Law, University of Silesia, Faculty of Earth Sciences, Chernivtsy-Sosnowiec, s. 40-44.

Dwucet K., 1986, Zróżnicowanie rzeźby na tle litologii utworów pytowych Płaskowyżu Rybnickiego, Uniwersytet Śląski, Katowice.

Działoszyńska-Wawrzkiewicz M., 2008, Metale ciężkie w osadach rzecznych terenów zurbanizowanych zlewni rzeki Kłodnicy, [w:] S. Hławiczek (red.), Metale ciężkie w środowisku, Wyd. Ekonomia i Środowisko, Białystok, s. 168-184.

Fajer M., 2018, Antropogenicznie uwarunkowane przełomy Suminy $i$ Wierzbnika jako przykład naturalizacji sztucznych koryt rzecznych (Płaskowyż Rybnicki i Kotlina Raciborska, potudniowa Polska), Prace Geograficzne, 153, 7-24.

Fajer M., Krąpiec M., Waga J.M., 2006, Cascade of the Ruda - past magnificence, Anthropogenic Aspects of Landscape Transformations, 4, 29-35.

Fajer M., Waga J.M., 2002, Pozostałości dawnego górnictwa $i$ hutnictwa żelaza $w$ okolicach Rud na Górnym Ślasku, [w:] P. Szwarczewski, E. Smolska (red.), Zapis działalności człowieka w środowisku przyrodniczym, 1, Wydz. Geogr. i Stud, Region. UW, Wyższa Szkoła Agrobiznesu w Łomży, Warszawa, s. 35-39.

Florek M., 2005, Archeologiczne przyczynki do poznania późnych procesów eolicznych wpótnocnej czesści Kotliny Sandomierskiej, [w:] M. Kuraś (red.), Archeologia Kotliny Sandomierskiej, Rocznik Muzeum Regionalnego w Stalowej Woli, 4, 143-153.

Gawor Ł., Szmatłoch A., 2010, Koncepcja waloryzacji zwałowisk po górnictwie węgla kamiennego na przykładzie Górnoślaskiego Zagłębia Weglowego, Acta Geographica Silesiana, 7, 23-29.

Gębica P., 1995, Ewolucja doliny Wisty pomiędzy Nowym Brzeskiem a Opatowcem w vistulianie i holocenie, Dokumentacja Geograficzna, 2, 1-89.

Gębica P., 2004, Przebieg akumulacji rzecznej w górnym vistulianie w Kotlinie Sandomierskiej, Prace Geograficzne IGiPZ PAN, 193, 1-229.

Gębica P., Bluszcz A., Woronko B., 2016, Geneza i wiek wydmy w Dąbrówkach (Kotlina Sandomierska, dolina Wistoka) w świetle analiz litologicznych osadów i datowań OSL, [w:] J. Święchowicz, A. Michno (red.), Wybrane zagadnienia geomorfologii eolicznej, Instytut Geografii i GP UJ, s. 305-330.

Gębica P., Sokołowski T., 1999, Catastrophic geomorphic processes and sedimentation in the Vistula valley between Dunajec and Witoka mouths during the 1997 flood, southern Poland, Quaternary Studies in Poland, Spec. Issue, 253-261.

Gębica P., Sokołowski T., 2001, Wstępne wyniki badań osadów stokowych Wysoczyzny Tarnowskiej w Górze Motycznej koło Dębicy, [w:] K. Klimek, K. Kocel (red.), Pokrywy stokowe jako zapis zmian klimatycznych w późnym vistulianie i holocenie, Sosnowiec, s. 11-13. 
Gębica P., Sokołowski T., 2002, Crevassing of an inland dune during the 1998 flood in the upper Vistula river valley (South Poland), Annales Societatis Geologorum Poloniae, 72, 191-197.

Gębica P., Starkel L., Cebulak E., Limanówka D., Pyrc R., Hajder M., Kolbusz J., 2019, Ulewy i powodzie opadowe $w$ województwie podkarpackim. Studium przebiegu, skutków i przeciwdziałania, Wydawnictwo Uniwersytetu Rzeszowskiego, Rzeszów.

Gębica P., Superson S., Trybała-Zawiślak K., Woronko B., 2017, Litologia, geneza $i$ wiek osadów w Kalnikowie i Chotyńcu na Płaskowyżu Tarnogrodzkim (Kotlina Sandomierska), Acta Geographica Lodziensia, 106, 65-86.

Gilewska S., 1999, Rzeźba, [w:] L. Starkel (red.), Geografia Polski. Środowisko przyrodnicze, Wydawnictwo Naukowe PWN, Warszawa, s. 243-288.

Gilot E., Niedziałkowska E., Sobolewska M., Starkel L., 1982, Pleniglacial alluvial Fan of the Biała Stream at Kaniów near Czechowice (the Oświęcim Basin), Studia Geomorphologica Carpatho-Balcanica, 15, 115-124.

Grygierczyk S., Pawełczyk W., Wach J., 1997, Formy po eksploatacji rud żelaza w pótnocno-wschodniej części Parku Krajobrazowego „Cysterskie Kompozycje Krajobrazowe Rud Wielkich” i ich walory przyrodniczo-kulturowe, Scripta Rudensia, 7, 63-74.

Grzesiak D., Trzepierczyński J., 2014, Ocena wpływu budowy pawilonu trójkondygnacyjnego na utratę stateczności zbocza w Jastrzębiu-Zdroju, Zeszyty Naukowe Wyższej Szkoły Technicznej w Katowicach, 6, 19-33.

Izmaiłow B., 2001, Typy wydm śródladowych $w$ świetle badan struktury $i$ tekstury ich osadów (na przyktadzie dorzecza górnej Wisty), Rozprawy Habilitacyjne UJ, 358, 1-282.

Jankowski A.T., 1986, Antropogeniczne zmiany stosunków wodnych na obszarze uprzemysłowionym i zurbanizowanym (na przykładzie ROW), Uniw. Śląski, Katowice.

Janusz W., Palki J., Zygmunt J., Węgrzyk A., 1982, Występowanie deformacji nieciagtych przy dużych głębokościach eksploatacji w Rybnickim Okręgu Węglowym, Mat. Konf. VIII Tydzień Techniki ROW, Zagadnienie ochrony powierzchni w ROW, Jastrzębie-Zdrój, s. 75-101.

Jary Z., 1996, Chronostratygrafia oraz warunki sedymentacji lessów potudniowo-zachodniej Polski na przykładzie Płaskowyżu Głubczyckiego i Wzgórz Trzebnickich, Acta Univ. Wratisl. Stud. Geogr., 1766, 1-99.

Jersak J., 1991, Lessy formacji umiarkowanie wilgotnej na Płaskowyżu Głubczyckim, [w:] J. Jersak (red.), Less i osady dolinne, Wyd. Uniwersytetu Śląskiego, Katowice, s. 10-49.

Karaś-Brzozowska C., 1963, Zasięg zlodowacenia środkowopolskiego w Kotlinie Raciborskiej, Przegląd Geograficzny, 35, 3, 431-447.

Kijowska M., 2011, The role of downpours in transformation of slopes in the Polish Carpathian Foothills, Studia Geomorphologica Carpatho-Balcanica, 45, 69-87.

Klimaszewski M., 1972, Podziat geomorfologiczny Polski Południowej, [w:] M. Klimaszewski (red.), Geomorfologia Polski, t. 1, Polska Potudniowa Góry i Wyżyny, PWN, Warszawa, s. 5-17.

Klimek K., 1983, Erozja wgłębna doptywów Wisty na przedpolu Karpat, [w:] Z. Kajak (red.), Ekologiczne podstawy zagospodarowania Wisty i jej dorzecza, PWN, Warszawa-Łódź, s. 97-108.

Klimek K., 1991, Typy koryt rzecznych $i$ ich funkcjonowanie, [w:] I. Dynowska, M. Maciejewski (red.), Dorzecze górnej Wisty, cz. 2, PWN, Warszawa-Kraków, s. 231-259.

Klimek K., 1995, Metale ciężkie w aluwiach Rudy (Górny Ślask) jako wskaźnik rolniczej i przemystowej antropopresji $w$ ostatnich stuleciach, mat. sympozjum polsko-czeskiego Przeobrażenia środowiska geograficznego w przyrodniczej strefie górnoślasko-ostrawskiego regionu przemysłowego, WNoZ UŚ, PK „CKKRW”, Sosnowiec, s. 48-56.

Klimek K., 1996, Aluwia Rudy jako wskaźnik 1000-letniej degradacji Płaskowyżu Rybnickiego, [w:] A. Kostrzewski (red.), Geneza, litologia i stratygrafia utworów czwartorzędowych, II, Wyd. UAM, Poznań, s. 155-166. 
Klimek K., 2007, Environmental causes and geomorphic record of Early Medieval colonization: South-Western Margin of the Rybnik Plateau and the neighbouring Odra valley, Geomorphologia Slovaca and Bohemica, 2, 5-13.

Klimek K., Krąpiec M., 2003, Subfosylne pnie w aluwiach Rudy jako zapis wptywu człowieka i/lub zmian klimatu na środowisko przyrodnicze doliny, Kotlina Górnej Odry, [w:] J.M. Waga, K. Kocel (red.), Człowiek w środowisku przyrodniczym - zapis działalności, Wyd. Oddz. Katowicki PTG, Sosnowiec, s. 79-83.

Klimek K., Starkel L., 1972, Kotliny Podkarpackie, [w:] M. Klimaszewski (red.), Geomorfologia Polski, t. 1, Polska Potudniowa Góry i Wyżyny, PWN, Warszawa, s. 116-166.

Klimek K., Woskowicz-Ślęzak B., 2016, Zapis wptywu rolnictwa w środowisku pasa wyżyn-przykład ze zlewni Bierawki (Wyżyna Ślaska), [w:] I. Malik, M. Wistuba, B. Woskowicz-Ślęzak (red.), Geomorfologiczny, sedymentologiczny i botaniczny zapis działalności człowieka $w$ wybranych strefach krajobrazowych Polski Potudniowej, Gliwice, s. 38-45.

Kocel K., 1995, Stawy $w$ dolinie Rudy (Górny Ślask) jako wskaźnik antropogenicznych zmian krajobrazu, mat. sympozjum polsko-czeskiego Przeobrażenia środowiska geograficznego w przyrodniczej strefie górnoślasko-ostrawskiego regionu przemysłowego, WNoZ US, PK „CKKRW”, Sosnowiec, s. 57-62.

Kocel K., 1997, Osady denne stawów jako wskaźnik zmian zaistniałych w środowisku przyrodniczym doliny Rudy, Scripta Rudensia, 7, 75-84.

Kondracki J., 1981, Geografia fizyczna Polski, PWN, Warszawa.

Krajewski R., Furmański J., Panasiuk A., Wagner S., 1968, Zjawiska osuwiskowe na obszarze górniczym kopalni $w$ Pszowie na tle stosunków geologicznych $w$ tym rejonie, Ochrona Terenów Górniczych, 6, 47-56.

Krajewski R., Rybicki S., Krokoszyński P., 1982, Problematyka osuwisk na terenach podziemnej eksploatacji górniczej, mat. sesji nauk. Badania geologiczno-inżynierskie w górnictwie, Kraków, s. 61-71.

Krokoszyński P., Rybicki S., 2010, Deformacje podtoża i przedpola składowiska odpadów górniczych „Pochwacie” - przyczyny, przebieg i skutki, Przegląd Górniczy, 66, 5, 30-37.

Kruczała A. (red.), 2000, Atlas klimatu województwa ślaskiego, IMGW, Oddział Katowice, Katowice.

Kruczkowski M., 1999, Deformacje nieciagłe typu liniowego na terenie miejscowości Gierałtowice jako przejaw intensywnej eksploatacji górniczej w niekorzystnych warunkach geologicznych, Bezpieczeństwo Pracy i Ochrona Środowiska w Górnictwie, 8, 41-45.

Lewakowski J., 1935, Mapa terenów powodzi lipcowej w 1934 r., Wiad. Służby Geogr., 9, 288-294.

Lewandowski J., 1993, Rzeźba podczwartorzędowa regionu śląso-krakowskiego i jej ewolucja morfogenetyczna, Folia Quaternaria, 64, 101-121.

Lewandowski J., 2015, Kenozoik regionu ślasko-krakowskiego, Wyd. Uniwersytetu Śląskiego, Katowice.

Łajczak A., 1995, The impact of river regulation, 1850-1990, on the channel and floodplain of the Upper Vistula River, Southern Poland, [w:] E.J. Hickin (red.), River Geomorphology, Wiley, s. 209-233.

Łajczak A., 2003, Silting of the Goczatkowice Reservoir, [w:] A.T. Jankowski, M. Rzętała (red.), Problemy geoekologiczne górnoślasko-ostrawskiego regionu przemysłowego, Uniwersytet Śląski, WNoZ, Sosnowiec, s. 96-101.

Łanczont M., Wojtanowicz J., 2005, Uwarunkowania przyrodnicze rozwoju osadnictwa pradziejowego w Kotlinie Sandomierskiej, [w:] M. Kuraś (red.), Archeologia Kotliny Sandomierskiej, Rocznik Muzeum Regionalnego w Stalowej Woli, 4, 39-55.

Mackiewicz D., Miksa K., Mrozowska A., 1979, Program uregulowania stosunków wodnych na obszarach objętych szkodami górniczymi w województwie katowickim, Hydroprojekt, CBSiPBW, Katowice. 
Migoń P., 2008, Wspótczesna ewolucja rzeźby Sudetów i ich Przedgórza, [w:] L. Starkel, A. Kostrzewski, A. Kotarba, K. Krzemień (red.), Wspótczesne przemiany rzeźby Polski, SGP, IGiGP UJ, IGiPZ PAN, Kraków, s. 135-163.

Niedbała W., 2003, Ekologia - organizmy żywe i ich środowisko, [w:] J. Strzałko, T. Mossor-Pietraszewska (red.), Kompendium wiedzy o ekologii, Wyd. Nauk. PWN, Warszawa, s. 42-118.

Niedziałkowska E., Gilot E., Pazdur M.F., Szczepanek K., 1985, The upper Vistula valley near Drogomyśl in the late Vistulian and Holocene, Folia Quaternaria, 56, 101-130.

Nocoń W., Kostecki M., 2005, Hydro-chemical characteristic of the Czarniawka River, Archiwum Ochrony Środowiska, 2, 95-104.

Nyrek A., 1966, Gospodarka rybna na Górnym Ślasku od połowy XVI do połowy XIX wieku, Prace Wrocławskiego Towarzystwa Naukowego, A, 111, 1-239.

Palki J., 1981, Zakres, formy i przyczyny występowania deformacji nieciagtych w warunkach Rybnickiego Okręu Wegglowego, Ochrona Terenów Górniczych, 56, 15-22.

Pełka J., Pociecha J., 1991, Zmiany terytorialne w rozmieszczeniu zwałowisk górniczych na obszarze Rybnickiego Okręu Weglowego w latach 1861-1986, Kształtowanie Środowiska Geograficznego i Ochrona Przyrody na Obszarach Uprzemysłowionych i Zurbanizowanych, 2, 5-10.

Pełka-Gościniak J., Szczypek T., 1997, Wptyw hatd górnictwa wegla kamiennego na krajobraz Rybnickiego Okregu Weglowego (na przykładzie okolic Wodzisławia Ślaskiego), [w:] J. Kanok, J. Prasek (red.), Zmeny geografickeho prostredi $v$ pohranicnich oblastech ostravskeho a hornoslezskeho regionu, Ostravska Univerzita, PF, Uniwersytet Śląski, WNoZ, Ostrava-Sosnowiec, s. 102-110.

Piech E., 1998, Ziemne budowle hydrotechniczne w zlewni Rudy od Zbiornika Rybnickiego po ujście Odry, Uniwersytet Śląski, WNoZ UŚ, Sosnowiec (praca magisterska).

Pozzi M., Cempiel E., Czajkowska A., 2008, Koncepcja regulacji stosunków wodnych na terenie górniczym gminy Gierattowice, Gospodarka Surowcami Mineralnymi, 24, 2/3, 109-122.

Przegladowa mapa geomorfologiczna Polski 1:500 000, 1980, IGiPZ PAN.

Puchejda A., 1978, Aktualne procesy osuwiskowe we wschodniej części Kotliny Raciborskiej, Instytut Geografii, Uniwersytet Śląski, WNoZ UŚ, Sosnowiec (praca magisterska).

Punzet J., 1981, Zmiany w przebiegu stanów wody w dorzeczu górnej Wisty na przestrzeni 100 lat (1871-1970), Folia Geogr., ser. Geogr.-Physica, 14, 5-28.

Punzet J., 1983, Zasoby wodne dorzecza górnej Wisty. Przeptywy średnie - rozkład sezonowy oraz zmienność w czasie i przestrzeni, Roczniki Nauk Rolniczych, ser. D, 192, 84-92.

Radosz J., 2007, Przewietrzanie dolin w okolicy Jastrzębia-Zdroju (Płaskowyż Rybnicki), Kształtowanie Środowiska Geograficznego i Ochrona Przyrody na Obszarach Uprzemysłowionych i Zurbanizowanych, 38, 23-32.

Rzętała M., 2008, Funkcjonowanie zbiorników oraz przebieg procesów limnicznych $w$ warunkach zróżnicowanej antropopresji na przykładzie regionu górnoślaskiego, Wyd. Uniwersytetu Śląskiego, Katowice.

Rzętała M.A., 2003, Procesy brzegowe i osady denne wybranych zbiorników wodnych $w$ warunkach zróżnicowanej antropopresji (na przykładzie Wyżyny Ślaskiej i jej obrzeży), Wyd. Uniwersytetu Śląskiego, Katowice.

Serwis IMGW-BIP Klimat Polski (klimat.pogodynka.pl/pl/climate-maps/).

Starkel L., 1967, Wisła wśród gór i wyżyn, [w:] C. Kolago (red.), Z biegiem Wisty. Przewodnik geologiczno-krajoznawczy, Wydawnictwa Geologiczne, Warszawa, s. 31-159.

Starkel L., 1972, Kotlina Sandomierska, [w:] M. Klimaszewski (red.), Geomorfologia Polski, t. 1, PWN, Warszawa, s. 138-166.

Starkel L., 1980, Rzeźba, [w:] I. Dynowska (red.), Województwo tarnowskie, s. 19-28.

Starkel L., 1996, Geomorphic role of extreme rainfalls in the Polish Carpathians, Studia Geomorphologica Carpatho-Balcanica, 30, 18-34. 
Starkel L., 1998, Funkcja powodzi w środowisku przyrodniczym dorzecza górnej Wisty, [w:] L. Starkel, J. Grela (red.), Powódź w dorzeczu górnej Wisty w lipcu 1997 roku, konferencja naukowa w Krakowie, 7-9 maja 1998, s. 9-20.

Starkel L., 2001, Historia doliny Wisty od ostatniego zlodowacenia do dziś, Monografie IGiPZPAN, $1,1-263$.

Starkel L., 2005, Typy rzeźby Kotliny Sandomierskiej i ich rola w osadnictwie (wprowadzenie do sesji: środowiskowe uwarunkowania osadnictwa pradziejowego w Kotlinie Sandomierskiej), [w:] M. Kuraś (red.), Archeologia Kotliny Sandomierskiej, Rocznik Muzeum Regionalnego w Stalowej Woli, 4, 11-17.

Starkel L., 2011, Złożoność czasowa i przestrzenna opadów ekstremalnych - ich efekty geomorfologiczne $i$ drogi przeciwdziałania im, Landform Analysis, 15, 65-80.

Szczepankiewicz S., 1972, Nizina Ślaska, [w:] R. Galon (red.), Geomorfologia Polski, t. 2, Niż Polski, PWN, Warszawa, s. 224-239.

Śleziak T., 1997, Antropogeniczne formy związane z gospodarka wodna we wschodniej części Parku Krajobrazowego „Cysterskie Kompozycje Krajobrazowe Rud Wielkich”, Uniwersytet Śląski, WNoZ UŚ, Sosnowiec (praca magisterska).

Święchowicz J., 2010, Ekstremalne sptukiwanie $i$ erozja linijna na stokach użytkowanych rolniczo w polskich Karpatach fliszowych, Prace i Studia Geograficzne, 45, 29-48.

Wach J., 1987, Zmiany profilu podtużnego Kłodnicy w wyniku osiadan górniczych, mat. sympozjum polsko-czechosłowackiego Problemy geograficzne górnoślasko-ostrawskiego regionu przemystowego, Oddz. Doskonalenia Nauczycieli IKN, Uniwersytet Śląski, Katowice-Sosnowiec, s. $126-130$.

Waga J.M., 1992, Profil osadów plejstoceńskich w Golasowicach (Brama Bąkowska), Geographia, Studia et Dissertationes, 16, 117-134.

Waga J.M., 1994, Rzeźba eoliczna na obszarze wschodniej części Niecki Kozielskiej, Scripta Rudensia, 2, 1-129.

Waga J.M., 2003, Lokalizacja stawów $i$ sposoby ich zabezpieczania przed skutkami powodzi $w$ dolnej części zlewni Rudy na Górnym Ślasku, [w:] J.M. Waga, K. Kocel (red.), Człowiek w środowisku przyrodniczym - zapis działalności, PTG Oddział Katowicki, Sosnowiec, s. 220-224.

Waga J.M., 2009, Specyficzne cechy zjawisk eolicznych ze schytku piętra wisty w Niecce Kozielskiej, [w:] R. Dulias, J. Pełka-Gościniak, O. Rahmonov (red.), Ekosystemy piaszczyste i człowiek, Prace Wydziału Nauk o Ziemi Uniwersytetu Śląskiego, 58, 163-171.

Waga J.M., Fajer M., 2020, Grodziska i osuwiska - przykłady wykorzystania osuwisk jako naturalnych elementów dawnych założeń obronnych (Kotlina Raciborsko-Oświęcimska), Acta Geographica Silesiana, 14/4 (40), 31-62.

Waga J.M., Fajer M., 2021a, Formy osuwiskowe w południowo-zachodniej części Kotliny Oświęcimskiej - rozmieszczenie i uwarunkowania rozwoju, Prace i Studia Geograficzne, złożone do druku.

Waga J.M., Fajer M., 2021b, The heritage of the Second World War: bombing in the forests and wetlands of the Koźle Basin, Antiquity, 95, 380, 417-434.

Wieland Z.J., 1988, Wąwóz lessowy w Miejscu Odrzańskim, Uniwersytet Śląski, Wydział Nauk o Ziemi, Sosnowiec (praca magisterska).

Wojtanowicz J., 1971, Typy genetyczne wydm Niziny Sandomierskiej, Annales UMCS, sec. B, 25, $1-45$.

Wojtanowicz J., 1972, Rzeźba eoliczna na pótnocnym przedpolu Płaskowyżu Kolbuszowskiego, Annales UMCS, sec. B, 27, 1-20.

Wojtanowicz J., 1997, Późnovistuliańskie osady pylaste Płaskowyżu Kolbuszowskiego okolic Leżajska w profilu Grodzisko Dolne, [w:] M. Łanczont (red.), Glacjat i peryglacjat Kotliny Sandomierskiej i przedgórza Karpat w okolicy Przemyśla, Krasiczyn 22-24 września 1997, s. 110-112.

Wojtanowicz J., 2010, Wspótczesne procesy eoliczne, Wyd. UMCS, Lublin. 
Wojtanowicz J., Jóźwiakowska E., 1997, Jeziorka okolic Grodziska - występowanie, charakterystyka, [w:] M. Łanczont (red.), Glacjat i peryglacjat Kotliny Sandomierskiej i przedgórza Karpat w okolicy Przemyśla, Krasiczyn 22-24 września 1997, s. 113-123.

Woskowicz-Ślęzak B., 2013, Funkcjonowanie żwirodennej rzeki roztokowej na pótnocnym przedpolu Karpat na przykładzie Soty od końca XVIII wieku, Uniwersytet Śląski, WNoZ Sosnowiec (praca doktorska).

Woskowicz-Ślęzak B., Ślęzak A., 2012, Zapis antropopresji w rzeźbie przedgórskiego odcinka dna doliny Soty, [w:] A. Łajczak (red.), Antropopresja w wybranych strefach morfoklimatycznych - zapis zmian w rzeźbie i osadach, Uniwersytet Śląski, WNoZ, Sosnowiec, s. 441-452.

Zieliński P., Sokołowski R.J, Woronko B., Jankowski M., Fedorowicz S., Zaleski I., Molodkov A., Weckwerth P., 2014, The depositional conditions of the fluvio-aeolian succession during the last climate minimum based on the examples from Poland and NW Ukraine, Quaternary International 386, 30-41.

Zygmunt E., 2002, Transformacja koryta rzeki Suminy pod wptywem antropopresji (Kotlina Raciborska, Dorzecze Górnej Odry), [w:] P. Szwarczewski, E. Smolska (red.), Zapis działalności człowieka w środowisku przyrodniczym, Warszawa, s. 151-154.

Zygmunt E., 2003, Zmiana biegu rzeki Suminy pod wptywem antropopresji (Kotlina Raciborska) [w:] J.M. Waga, K. Kocel (red.), Człowiek w środowisku przyrodniczym - zapis działalności, PTG Oddział Katowicki, Sosnowiec, s. 244-248. 